\title{
Discussão dos processos de construção do complexo granítico São Sepé, RS: feições geológicas e petrográficas
}

\author{
Maria do Carmo GASTAL ${ }^{1}$ \& Francisco J. F. FERREIRA ${ }^{2}$
}

1. Departamento de Mineralogia e Petrologia, Instituto de Geociências, Universidade Federal do Rio Grande do Sul. Caixa Postal 15.022, CEP 91501-970, Porto Alegre, RS, Brasil. E-mail: maria.gastal@ufrgs.br.

2. Laboratório de Pesquisas em Geofísica Aplicada, Departamento de Geologia, Universidade Federal do Paraná. Caixa Posta 19.045, CEP 81531-980, Curitiba, PR, Brasil. E-mail: francisco.ferreira@ufpr.br.

Recebido em 12/2012. Aceito para publicação em 10/2013.

Versão online publicada em 02/12/2013 (www.pesquisasemgeociencias.ufrgs.br)

\begin{abstract}
Resumo- A construção do complexo granítico São Sepé (CGSS) é discutida a partir de informações de campo, geológicas e estruturais, complementadas com a avaliação dos sistemas tectônicos regionais integrando sensores remotos (MDE-SRTM e imagem ASTER) e mapas aeromagnetométricos, e com a investigação detalhada de texturas e estruturas. O CGSS, localizado no oeste do Escudo Sul-riograndense (Bloco São Gabriel), representa os níveis epizonais (250-160 MPa) de uma coluna vertical de magma-mush com atividade moderada, controlada por zonas de falha pré-existentes $\mathrm{N} 30-35^{\circ} \mathrm{E}$ e $\mathrm{N} 55-60^{\circ} \mathrm{W}$, cuja atividade foi vinculada aos eventos pós-colisionais da Orogênese Dom Feliciano (640-620 Ma). Sua formação ocorreu no final do Neoproterozóico (570-560 Ma), durante evento tectônico transtensivo ao longo de zonas de falha N15-20 ${ }^{\circ} \mathrm{E}$, responsável pelo soerguimento regional e expressivo magmatismo ácido, que é reflexo de orogenias mais jovens ocorridas a norte. É um pluton composto de dimensão moderada $\left(473 \mathrm{~km}^{2}\right)$, consistindo de monzogranitos centrais e sienogranitos na borda, que exibem grande variedade de texturas. A expansão do sistema magmático com acúmulo de voláteis no final de sua formação, como registrado pela cúpula granítica e ampla margem resfriada félsica, teria promovido a reativação do sistema de falhas NW-SE. Isto permite inferir o papel, mesmo reduzido, de mecanismos de alojamento via o soerguimento do teto. De acordo com o modelo proposto, a construção do CGSS decorre de episódios progressivos e cíclicos de recarga com magma máfico na base de uma soleira sienogranítica precursora, o que é registrado por feições diversificadas de hibridismo nos monzogranitos. Isto acarretou a estratificação do magma residente, que inicia a cristalizar separadamente: monzogranitos hibridizados na base, e sienogranitos a partir de líquidos magmáticos residuais coletados no topo, cuja cristalização foi sucessivamente postergada com a concentração de voláteis $\left(\mathrm{H}_{2} \mathrm{O}\right.$ e F). Episódios subsequentes de recarga máfica, em uma intrusão mais fria e parcialmente solidificada, promoveram o reaquecimento e a consequente maturidade textural e erosão termal das fácies cristalizadas; a remobilização de mushes cristalinos, com reintrusão e co-mingling de magmas hibridizados; e o maior subresfriamento termal no polo máfico. Tais feições apontam para o acúmulo de magmas sienograníticos altamente móveis, que sustentaram uma das câmaras magmáticas alimentadoras do vulcanismo coevo (Formação Acampamento Velho).
\end{abstract}

Palavras-Chave: pluton multicíclico, recarga máfica, cúpula granítica félsica, texturas de dissolução, lineamentos tectônicos.

Abstract - Discussion of CONSTRUCTION PRoCESSES For the SÃo SEPÉ GRANitic CoMPleX, SOUTHERNMOST BRAZIL: GEOLOGICAL AND PETROGRAPHIC FEATURES. Construction processes for the São Sepé granitic complex (SSGC) are discussed on the basis of geological and structural, field informations complemented by integrated studies of remote sensors (DEM-SRTM and ASTER images) and aeromagnetic maps for analyzing regional tectonic systems, and also by detailed petrographic investigation. The granitic complex, located in the west of the Sul-riograndense Shield (São Gabriel Block), represents the shallow level (250-160 MPa) of a vertical slow-production mush column controlled by $\mathrm{N} 30-35^{\circ} \mathrm{E}$ and $\mathrm{N} 55-60^{\circ} \mathrm{W}$, pre-existents fault zones linked to post-collisional events of the Dom Feliciano Orogeny (640-620 Ma). Its formation occurred during transtensive tectonic event along $\mathrm{N} 15-20^{\circ} \mathrm{E}$ fault zones, responsible for regional uplifting and extensive magmatic events at the end of the Neoproterozoic (570-560 Ma), as a reflex of some younger orogeny in the north. The SSGC is a moderate-size (473 $\mathrm{km}^{2}$ ), composite pluton composed of monzogranites in the center and syenogranites in the border, showing wide textural variations. The expansion of the magma system caused by volatile accumulation at the end of its formation, as registered by granitic cupola and wide felsic margins, has induced the reactivation of NW-SE fault zones. Consequently, this leads to infer some emplacement mechanisms involving roof uplifting. According to the model proposed, the SSGC was constructed through progressive and cyclic, mafic recharge at the bottom of a precursor syenogranite sill, which are put in evidence by features of hybridism in monzogranites. The result was the stratification of the resident magma, and the pluton started to crystallize separately: hybridized monzogranites at the base; and syenogranites from residual melts at the top, in which the concentration 
of $\mathrm{F}-\mathrm{H}_{2} \mathrm{O}$-rich volatiles postponed the crystallization successively. Next episodes of mafic replenishments in a cold, partially crystallized intrusion resulted in re-heating leading to textural aging and thermal erosion of crystallized facies; the reactivation of crystal mushes with re-intrusion and co-mingling of hybridized magmas; and large thermal undercooling of the mafic pole. These features suggest the accumulation of highly mobile syenogranitic magmas on the top, which has built up one of the active magma chambers feeding of the coeval volcanism (Acampamento Velho Formation).

Keywords: multicyclic pluton, mafic recharge, felsic granite cupola, dissolution textures, tectonic lineaments.

\section{Introdução}

O complexo granítico São Sepé (CGSS) integra o magmatismo ácido do final do Neoproterozóico ao Eo-Paleozóico no oeste do Escudo Sul-riograndense, pós-colisional da Orogênese Dom Feliciano (680-580 Ma) ou reflexo da Orogênese Rio Doce (590-530 Ma).É uma intrusão de epizona que exibe grande variedade de texturas e zonação reversa das fácies petrográficas, com monzogranitos no centro e sienogranitos na borda. Este complexo granítico é entendido ora como um pluton composto ou múltiplo (Sartori, 1978; Gastal, 1998), ora como duas intrusões distintas designadas de granito São Sepé (sienogranito e microgranitos da borda) e monzogranito Rincão dos Coqueiros (Porcher et al., 1995). A ideia de intrusões múltiplas é antiga (e.g. Buddington, 1959; Pitcher, 1978), contudo, os modelos tradicionais assumem um volume considerável de magma posicionado na crosta quase instantaneamente.

0 refinamento destes conceitos está na pauta do debate atual (Coleman et al., 2004; Matzel et al., 2006; Walker et al., 2007; Miller et al., 2011). A construção de uma intrusão, na visão atual, envolve processos de alojamento (emplacement) e amalgamação de pulsos de magma (assembly), que operam simultaneamente e podem variar no tempo e espaço em escalas distintas (Bartley et al., 2008; Horsman et al., 2010; Menand, 2011). Dependendo das taxas de abastecimento de magma e da habilidade em amalgamar, os pulsos solidificam rapidamente ou acumulam e coalescem, sustentando câmaras magmáticas com atividade episódica, periódica ou prolongada (Annen, 2009; Michaut \& Jaupart, 2011). Uma questão ainda crítica se refere à interpretação de estruturas e texturas na identificação e caracterização de unidades básicas (pulsos - incrementos), e daquelas parcelas representativas de magmas potencialmente eruptivos (Harper et al., 2004; Lux et al., 2007; Horsman et al., 2010; du Bray et al., 2011; Miller et al., 2011). Os contatos internos podem ser gradativos, bruscos ou crípticos dependendo da distribuição de temperatura no tempo e espaço. Além disso, processos sucessivos de alojamento-amalgamação durante o crescimento do pluton mascaram ou destroem os registros da pulsação de magma, o que é agravado com a deformação tectônica. Na medida em que a dimensão e o tempo de sua formação são vinculados, os registros observados podem ter significados distintos (de Saint Blanquat et al., 2011). Estes tendem a ser preservados naqueles pequenos $\left(\leq 300 \mathrm{~km}^{3}\right)$, e apagados nos maiores onde os contrastes composicionais revelam ciclos intrusivos em função dos processos de geração de magma.

De outro lado, o fato da maioria dos plutons graníticos exibir forma 3D grosseiramente tabular, independente do ambiente tectônico (Cruden, 1998; Vigneresse et al. 1999), pressupõe processos similares de desenvolvimento. Isto acarretou a revisão dos mecanismos de alojamento. Assim, em condições de epizona, estes envolvem o espalhamento lateral de magma ao nível do posicionamento e o deslocamento vertical das encaixantes (soerguimento do teto e abatimento do assoalho), ambos influenciados pela deformação frágil (Petford et al., 2000; Cruden \& McCaffrey, 2001). Neste contexto, descontinuidades e heterogeneidades crustais são os principais condicionantes do posicionamento da intrusão (Hogan et al., 1998; Gudmundsson, 2011), enquanto a transferência vertical de massa está associada à movimentação de falhas regionais ou reativação daquelas pré-existentes (Grocott et al., 2009). Descontinuidades crustais como zonas de falha e de cisalhamento dúctil, ao servirem de dutos para os magmas, tendem também a controlar a distribuição espacial dos centros magmáticos (Corti et al., 2005; Kokkalas \& Aydin, 2013). 0 entendimento da formação destes centros requer, então, a investigação conjunta do desenvolvimento petrológico e estrutural (padrões de propagação de acordo com parâmetros internos e externos). Não obstante a complexidade da deformação frágil em terrenos mais antigos, a evolução de estruturas frágeis é discutida para plutons graníticos rasos e no âmbito regional (e.g. Kirkland et al., 2008; Viola et al., 2012).

Características como natureza múltipla, diversidade de texturas e dimensão moderada $\left(\approx 473 \mathrm{~km}^{2}\right)$, aliadas ao posicionamento na epizona durante tectônica transtensiva, fazem do CGSS um exemplo para revisar os registros de processos magmáticos na construção de um pluton. São resumidos os aspectos geológicos e petrográficos visando discutir o modelo de sua construção. Texturas e estruturas, em meso e microescalas, são detalhadas à luz do debate sobre a construção de reservatórios de magma na crosta média e superior, em pulsos sucessivos ou ciclos intrusivos. Lineamentos regionais, avaliados a partir de sensores remotos, fornecem a base para analisar sua relação com os sistemas tectônicos regionais. Tal caracterização preliminar se faz necessária, dado que a arquitetura e evolução de estruturas frágeis são pouco exploradas nesta região. 
A denominação de complexo granítico São Sepé foi mantida uma vez que traduz a ambiguidade nas relações de intrusão entre os dois grupos de granitos, e está de acordo com o International Stratigraphic guide (IUGS - International Union of Geological Sciences: www.stratigraphy.org/index.php/ICS-stratigraphicguide; cap. 5). Adotamos o termo pluton para definir uma estrutura intrusiva de forma irregular e dimensões moderadas, construída por um ou mais pulsos de magma, a qual é claramente circunscrita pelo envelope encaixante (Pitcher, 1997). De acordo com as ideias atuais, então, os plutons podem variar de simples e homogêneos a múltiplos e compostos.

\section{Materiais e métodos}

Para caracterização preliminar de estruturas tectônicas regionais, reunimos dados básicos de sensores remotos (modelo digital de elevação - MDE e imagem de satélite ASTER), cuja interpretação é integrada a mapas geológicos e aeromagnetométricos. 0 mapa de alinhamentos e lineamentos foi elaborado a partir do modelo digital de elevação derivado do SRTM (Shuttle Radar Topography Mission, NASA-USGS, 2000; resolução de $90 \mathrm{~m}$ ). Adotamos como alinhamento qualquer feição linear do relevo com extensão superior a $4-5 \mathrm{~km}$, retilínea ou curva, enquanto lineamento foi definido em regiões de maior extensão e densidade de alinhamentos (Veneziani \& Anjos, 1982). Ambos foram extraídos manualmente a partir do MDE-SRTM, realçado pelo gradiente de relevo, o qual é menos suscetível a distorções decorrentes da iluminação (Hiller \& Smith, 2008). As imagens de gradiente de relevo foram pseudo-iluminadas côm fontes em diferentes azimutes, a fim de evitar a supervalorização de alinhamentos ortogonais a essas direções. Os resultados foram checados e detalhados com a imagem de satélite ASTER (ASTL1B-0701011342131205100057), incluindo três bandas VNIR (visível e infravermelho próximo, resolução de $15 \mathrm{~m}$ ) e seis SWIR (infravermelho de ondas curtas, resolução de $30 \mathrm{~m}$ ). Foram aplicadas as correções geográficas, e as bandas SWIR reamostradas para resolução de $15 \mathrm{~m}$. Os dados magnetométricos originais do Projeto Aerogeofísico Camaquã (Área 1), obtidos segundo linhas de voo de direção $\mathrm{N} 45^{\circ} \mathrm{W}$ (espaçamento médio de $1 \mathrm{~km}$, altitude média de $125 \mathrm{~m}$, intervalo de amostragem de 137 m; Jackson et al., 1973), foram interpolados em malha regular com espaçamento de 250 m (1/4 da separação das linhas de voo) pelo método de curvatura mínima (Briggs, 1974), e posteriormente micronivelados (Minty, 1991). Ao mapa do campo magnético anômalo, resultado da remoção do modelo do IGRF (International Geomagnetic Reference Field para a época do levantamento), foram aplicados os filtros de realce que enfatizam o arcabouço estrutural, como os gradientes vertical e horizontal. A primeira e a segunda derivada vertical estimam as variações do campo anômalo nessa direção, sendo úteis para delimitar descon- tinuidades e ressaltar fontes rasas. Mudanças litológicas laterais abruptas ou estruturais são indicadas pelo gradiente horizontal total (GHT - Cordell \& Grauch, 1985). O mapa continuado para cima $(1000 \mathrm{~m})$ permite estimar o campo potencial acima do plano original de medição. Com isto, os sinais de pequeno comprimento de onda são reduzidos e as anomalias mais profundas realçadas. A amplitude do sinal analítico (Nabighian, 1972, 1974; Roest et al., 1992), foi também utilizada, uma vez que fornece a assinatura localizada da anomalia magnética sobre a fonte. Este é um método considerado como independente da magnetização induzida e da remanência da fonte, apesar das observações de Li (2006).

\section{Contexto regional}

\subsection{Arcabouço geológico}

A evolução de domínios geotectônicos no Escudo Sul-riograndense é relacionada à colagem de cinturões neoproterozóicos na borda leste do Craton Rio de la Plata (Fig. 1A). 0 Cinturão Dom Feliciano consiste no embasamento neoarqueano-paleoproterozóico retrabalhado e inclui o Batólito de Pelotas (640-580 Ma) e o Cinturão Porongos (800-700 Ma), que constituem respectivamente as porções leste e central do escudo. O climax colisional da Orogênese Dom Feliciano, entre 640-620 Ma, é marcado por zonas de cisalhamento esquerdas N30-40 ${ }^{\circ}$. Os blocos São Gabriel e Taquarembó, no oeste do escudo, atuaram como antepaís durante esta orogenia e compreendem, respectivamente, associações de arco magmático juvenil do Neoproterozóico (900-700 Ma) e da borda cratônica. O Cinturão Porongos e parte do Bloco São Gabriel estão cobertos pelas sequências da Bacia do Camaquã (630-470 Ma), cuja deposição foi contemporânea aos eventos magmáticos do final do Neoproterozóico ao Eo-Paleozóico. Estes eventos ígneos, expressos no oeste por plutons graníticos e sequências vulcanogênicas, são formados em dois períodos principais: 605-580 Ma e 575-535 Ma (Gastal et al., 2010). 0 primeiro, interpretado como pós-colisional da orogenia Dom Feliciano, compreende o vulcanismo intermediário da Formação Hilário e rochas graníticas metaluminosas e álcali-cálcicas (magnesianas ou ferrosas). 0 segundo episódio, contudo, tem sido também considerado reflexo de orogenias ocorridas a norte (Chemale Jr., 2000), como a Rio Doce (590-530 Ma, Campos Neto \& Figueiredo, 1995). Fazem parte deste evento, granitos metaluminosos e ferrosos (cálcio-alcalinos, álcali-cálcicos e alcalinos) e o vulcanismo da Formação Acampamento Velho, com riolitos e traquitos dominantes.

\subsection{Região norte do Bloco São Gabriel}

A região do arco magmático juvenil inclui as seguintes unidades litológicas, de oeste para leste (Fig. 

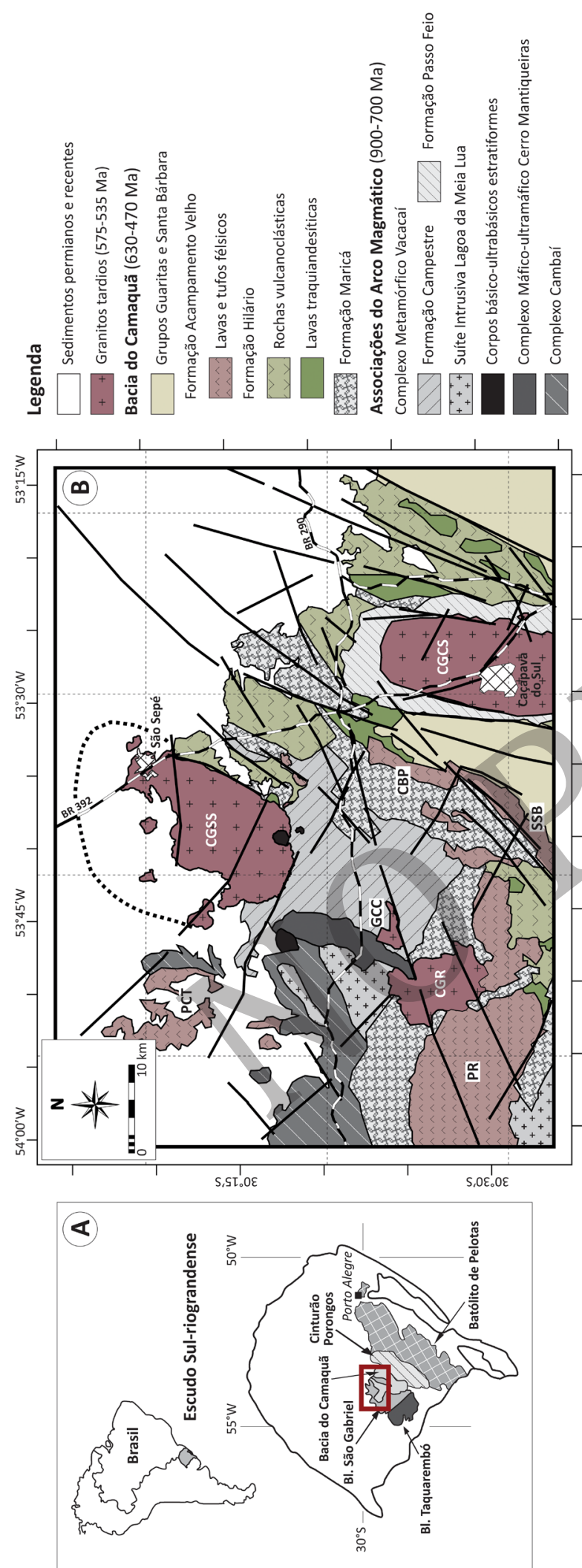

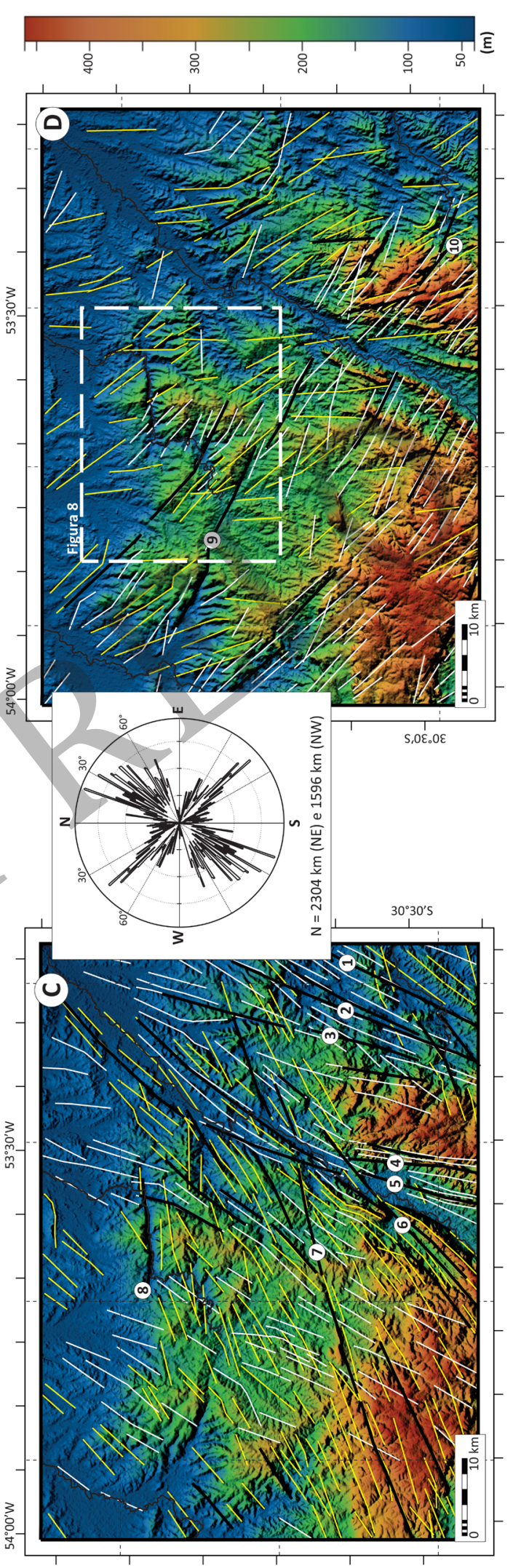

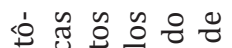

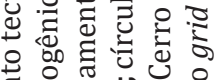

苞苛芯

ส

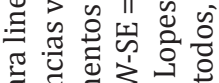

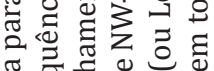

讨

하유

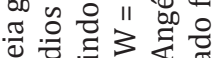

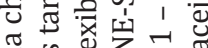

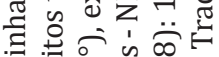

ㄷำ ᄂูํํำ

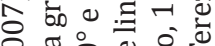

융의

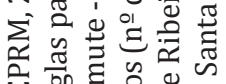

的雪。

일

政

槆

घ $>$ 대

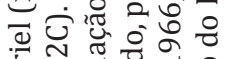

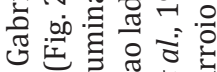

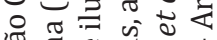

政

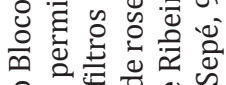

$\circ \pi \div \pi \frac{\pi}{0}$

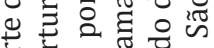

항ㅎㅁ

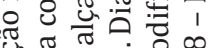

泡 $\pi$

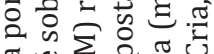

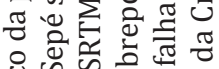

o i i o

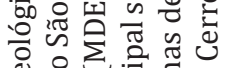

过记

证

$\sum^{\pi}$

i $x$

is

है

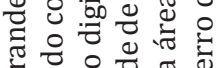

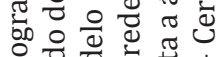

운

ज组它

원

리워

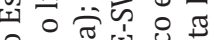

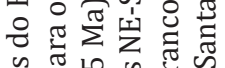

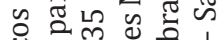

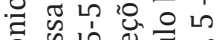

을 응

更

栆

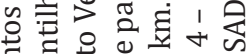

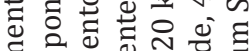

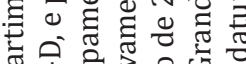

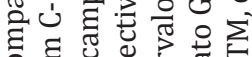

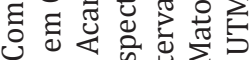

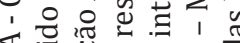

4 西的

ช

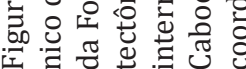


1B; CPRM, 2007): (a) Complexo Cambaí que reúne ortognaisses tonalito-trondhjemíticos, paragnaisses e ultramafitos de fácies anfibolito médio a inferior, afetados por tectônica de cavalgamento com vergência para SE $\left(D_{1}\right)$, transposta por cisalhamento subhorizontal N50-60 ${ }^{\circ}$ ( $\left.D_{2}\right)$ (Porcher \& Lopes, 2000); (b) Diorito e tonalitos separados em três ciclos intrusivos: tardi- $\mathrm{D}_{2} \mathrm{e}$ aqueles sin- e tardi-tectônicos à zona de cisalhamento vertical direita $\mathrm{N} 50-60^{\circ} \mathrm{E}\left(\mathrm{D}_{3}\right)$, agrupados na Suíte Intrusiva Lagoa da Meia Lua (UFRGS, 1997); (c) Ultramafitos do Complexo Cerro Mantiqueiras, que formam o Cinturão Bossoroca alongado na direção NNE-SSW; (d) Sequências metavulcanogênica e metapelítica do Complexo Metamórfico Vacacaí, as quais junto com a unidade anterior estão sobrepostas pela transcorrência $\mathrm{D}_{3}$; e (e) Corpos básico-ultrabásicos estratiformes (Pedras Pretas, Santa Catarina e Mata Grande). A Formação Passo Feio tem sido correlacionada a associações similares do Vacacaí, porém exibe assinatura isotópica do $\mathrm{Nd}$ não juvenil e está intercalada a rochas paleoproterozóicas (Saalmann et al., 2011). Forma uma antiforme alongada na direção N-S, com mergulho para NW e núcleo ocupado pelo complexo granítico Caçapava do Sul (Bitencourt, 1983).

As unidades neoproterozóicas da Bacia do Camaquã, expostas a leste e sul, incluem rochas sedimentares da Formação Maricá, e aquelas vulcanoclásticas e efusivas da Formação Hilário (Fig. 1B). 0 evento ígneo do Neoproterozóico/Eo-Paleozóico compreende os complexos graníticos São Sepé (CGSS), Caçapava do Sul (CGCS) e Ramada (CGR), o granito Cerro da Cria (GCC), e as vulcânicas dos platôs da Ramada (PR) e do Cerro Tupanci (PCT), dos cerros do Bugio e Perau (CBP), e da Serra de Santa Bárbara (SSB). Este evento ocorreu durante período de soerguimento regional em regime transtensivo, com deposição restrita a pequenos grabens controlados por falhas $\mathrm{N} 45-50^{\circ} \mathrm{E}$, ao passo que as unidades anteriores foram ainda afetadas pela tectônica compressiva do final da Orogênese Dom Feliciano (Borba et al., 2008). O CGCS, contudo, é uma intrusão sintectônica à zona de cisalhamento subvertical de direção $\mathrm{N} 15-20^{\circ} \mathrm{E}$ posicionada a oeste (Bitencourt, 1983), que deveria ter cinemática dextral como ressaltam Costa et al. (1995). As sequências cambro-ordovicianas da Bacia de Camaquã estão expostas a leste e a sul (grupos Guaritas e Santa Bárbara; CPRM, 2007).

\section{Lineamentos tectônicos}

Os lineamentos tectônicos expressivos correspondem a zonas de falha de direção N15-20 ${ }^{\circ} \mathrm{E}$ a N25-30 ${ }^{\circ} \mathrm{E}$ que delimitam o alto de Caçapava do Sul (Fig. 1C), e são agrupadas no Sistema de Falhas Irapuá (Ribeiro et al.,1966). Representam estruturas frágeis a frágil-dúcteis com movimento lateral esquerdo, embora cinemática dextral seja também referida. Os lineamentos $\mathrm{N} 25-30^{\circ} \mathrm{E}$ a leste do complexo granítico Caçapava do Sul (CGCS) são longos, densos e retilíneos (zonas de fa- lha - Z. F. Angélica, Cerro do Caboclo e Mato Grande), e controlam o contato entre as formações Hilário e Passo Feio e o Grupo Guaritas. No oeste do CGCS, os lineamentos são longos e curvos (Z. F. Segredo e Santa Bárbara), variando de $\mathrm{N} 15-20^{\circ} \mathrm{E}$ a $\mathrm{N} 30^{\circ} \mathrm{E}$. Estes interrompem e

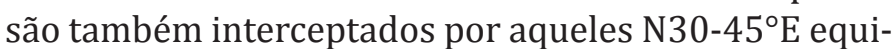
valentes à Z. F. Cerro dos Cabritos. Lineamentos N25$-30^{\circ} \mathrm{E}$ menores marcam o contato leste do complexo granítico São Sepé (CGSS) com as formações Hilário e Maricá, e destas com o complexo Vacacaí. Alinhamentos $\mathrm{N} 60-70^{\circ} \mathrm{E}$, curtos e interrompidos pelas demais direções, caracterizam a área de exposição das unidades do arco magmático e do Platô da Ramada. 0 lineamento mais expressivo corresponde à Z. F. Cerro da Cria, que controla o posicionamento de granitos tardios (CGR e GCC), e a leste é interrompida e deslocada pelo sistema Santa Bárbara-Cerro dos Cabritos. Os alinhamentos $\mathrm{N} 40-45^{\circ} \mathrm{W}$ a N55-60 ${ }^{\circ} \mathrm{W}$ exibem traços discretos no alto de Caçapava do Sul e a oeste, onde estão concentrados em duas faixas com lineamentos contínuos e curvos (Fig. 1D). Uma das faixas delimita, grosso modo, o Platô da Ramada e a outra equivale a zonas de falha que condicionam as vulcânicas do Cerro Tupanci e a porção sul do CGSS (Z. F. Arroio do Engenho). Os lineamentos NW-SE interceptam e deslocam com movimento esquerdo as direções $\mathrm{N} 40-50^{\circ} \mathrm{E}$, e aquelas $\mathrm{N} 25-30^{\circ} \mathrm{E}$ a leste do alto de Caçapava do Sul (Ribeiro, 1970), e são interrompidas pelo sistema $\mathrm{N} 15-20^{\circ} \mathrm{E}$ a oeste. Os alinhamentos NNW-SSE (N0-5 ${ }^{\circ} \mathrm{W}$ a $\left.\mathrm{N} 30^{\circ} \mathrm{W}\right)$ são mais expressivos na região de Caçapava do Sul, e aqueles ENE-WSW restritos às imediações do CGSS (Z. F. Rio São Sepé).

\section{Dados magnetométricos}

Os dados aeromagnetométricos possibilitam imagear as fontes de anomalias na crosta superior e média (em níveis crustais acima da isoterma Curie), sendo também efetivos na análise da arquitetura tectônica (Williams \& Betts, 2007; Crawford et al., 2010). As zonas de fraqueza crustais (zonas de falha e de cisalhamento dúctil) são locais em que ocorrem inúmeras transformações físicas e químicas decorrentes do deslocamento e da circulação de fluidos, que são responsáveis pela cominuição, alteração e neoformação de minerais, muitas vezes, ferromagnéticos. Tais processos são mais intensos em zonas de falha maduras, com amplas faixas de damage, as quais são comumente expressas por anomalias magnéticas alongadas, lineares ou sinuosas, de amplitude moderada a alta e gradientes abruptos. As estruturas mais rasas são identificadas por anomalias magnéticas alongadas de menor comprimento de onda e gradientes mais suaves, por gradientes lineares que truncam e deslocam estas, ou por quebras na resposta magnética onde tais anomalias estão ausentes (Crawford et al., 2010).

A distinção de dois domínios geofísico-estruturais é realçada no mapa da amplitude do sinal analítico (ASA - Fig. 2A). Valores moderados a baixos desta ca- 

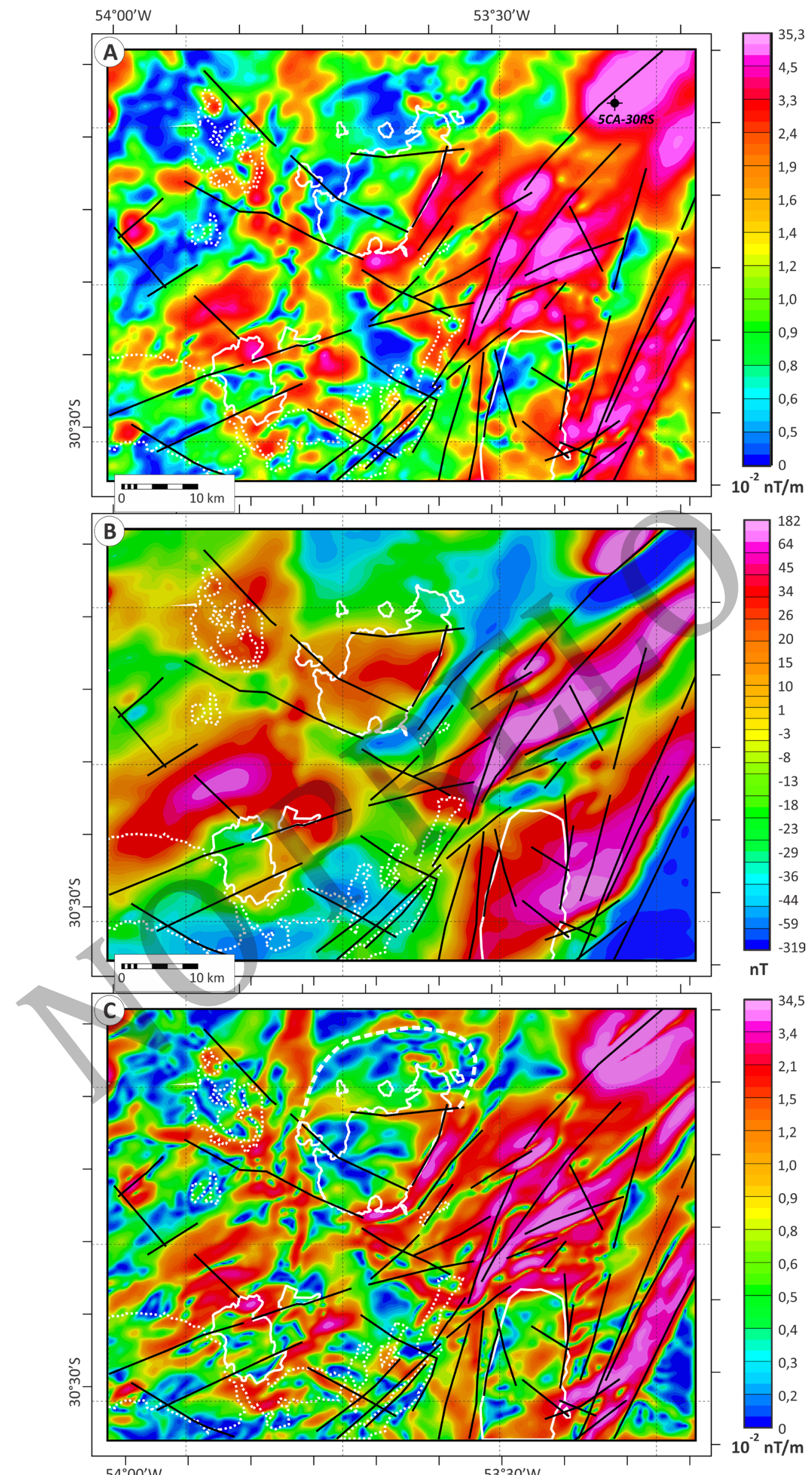

Figura 2. Mapas magnetométricos da porção norte do Bloco São Gabriel (Figs. 1B-D): A - Amplitude do sinal analítico (ASA), em que está localizado o furo de sondagem referido por Ribeiro (1978; 5CA-30RS); B - Continuação para cima (1000 m); C - Gradiente horizontal total (GHT). Linhas em A-C: branca contínua - para o contorno dos granitos tardios (575-535 Ma), e pontilhada - Formação Acampamento Velho; linha preta contínua para lineamentos tectônicos como nas figuras 1C-D; e linha tracejada branca grossa em C para o limite do complexo granítico São Sepé sob a cobertura permiana. Malha de coordenadas UTM como na figura 1. 


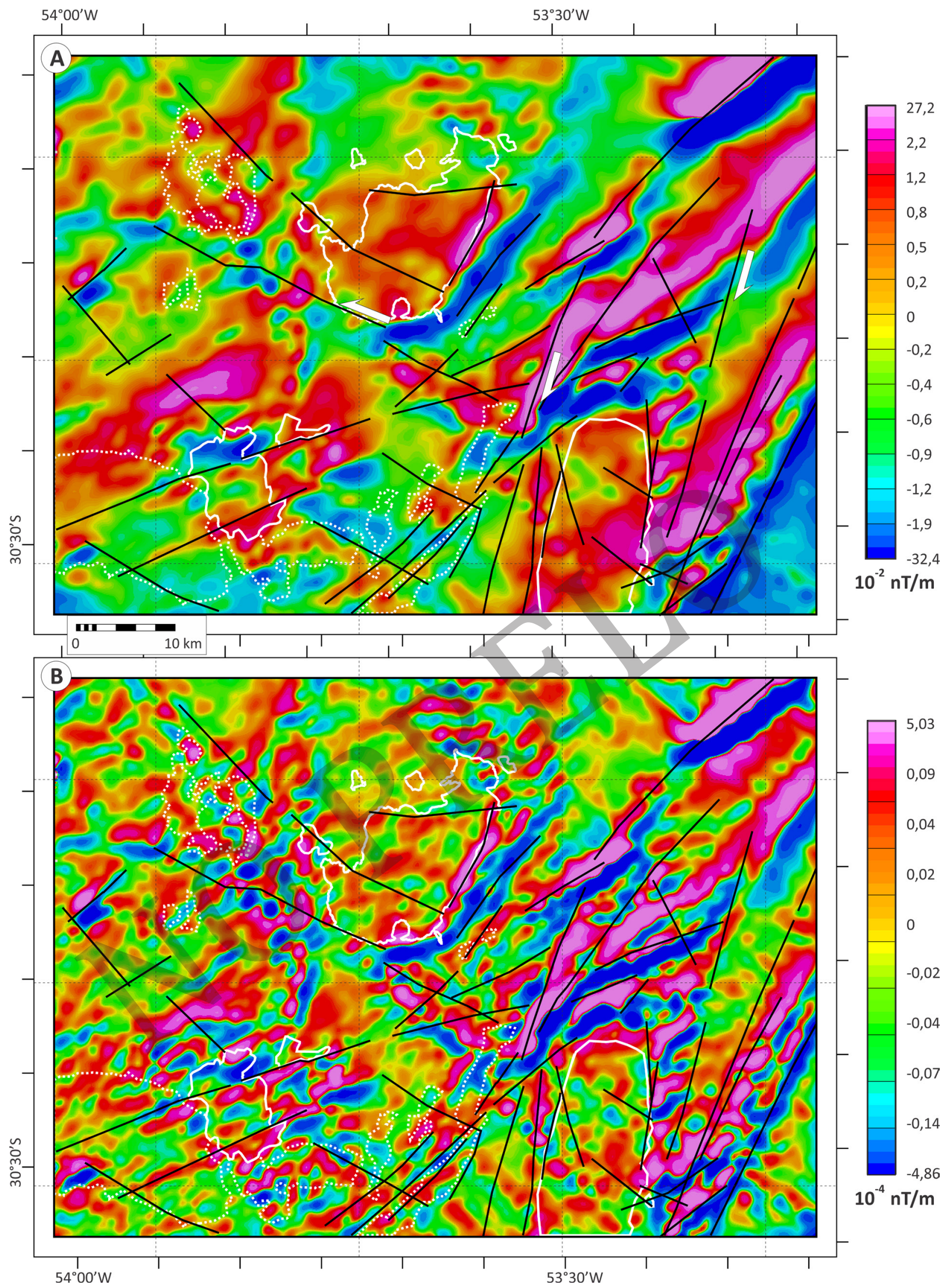

Figura 3. Mapa de gradiente magnético vertical para a porção norte do Bloco São Gabriel (Fig. 1): A - Primeira derivada (Dz1); B - Segunda derivada (Dz2). Seta em A indica o sentido de movimento sugerido para lineamentos magnéticos; e demais linhas como na figura 2. Malha de coordenadas UTM como na figura 1. 
racterizam o domínio centro-oeste, que compreende as exposições das unidades do arco magmático, platôs vulcânicos da Ramada e Cerro Tupanci, sub-bacia Santa Bárbara e da cobertura permiana no noroeste. 0 principal alto magnético relativo, ampliado em profundidade, corresponde ao contato entre os gnaisses Cambaí e granitóides Lagoa da Meia Lua (Figs. 2A-B). Os lineamentos magnéticos $\mathrm{N} 50-70^{\circ} \mathrm{W}$ são discretos, descontínuos, com gradientes mais suaves e amplitude baixa a moderada, como é o caso daqueles que caracterizam as zonas de falha Cerro da Cria e Cerro dos Cabritos (Fig. $3)$. Contudo, a primeira é melhor expressa por quebras na resposta magnética em profundidade (Fig. 2B). As zonas de falha N15-20 $2{ }^{\circ}$ (Santa Bárbara e Segredo), a oeste do CGCS, correspondem a lineamentos também marcados por quebras na resposta magnética, porém a Z. F. Santa Bárbara é mais evidente em profundidade (Figs. 2B-C e 3). Lineamento magnético N-S discreto ocorre a oeste do CGSS (Figs. 2C e 3), e sua continuidade para sul corresponde ao limite leste do Cinturão Bossoroca. Este lineamento tem pouca expressão em superfície (Figs. 1C-D), sendo identificado nos mapas magnéticos por quebra na resposta (Figs. 2A e C) e gradientes lineares que truncam os lineamentos NE-SW (Fig. 3).

Amplitudes elevadas do sinal analítico caracte-

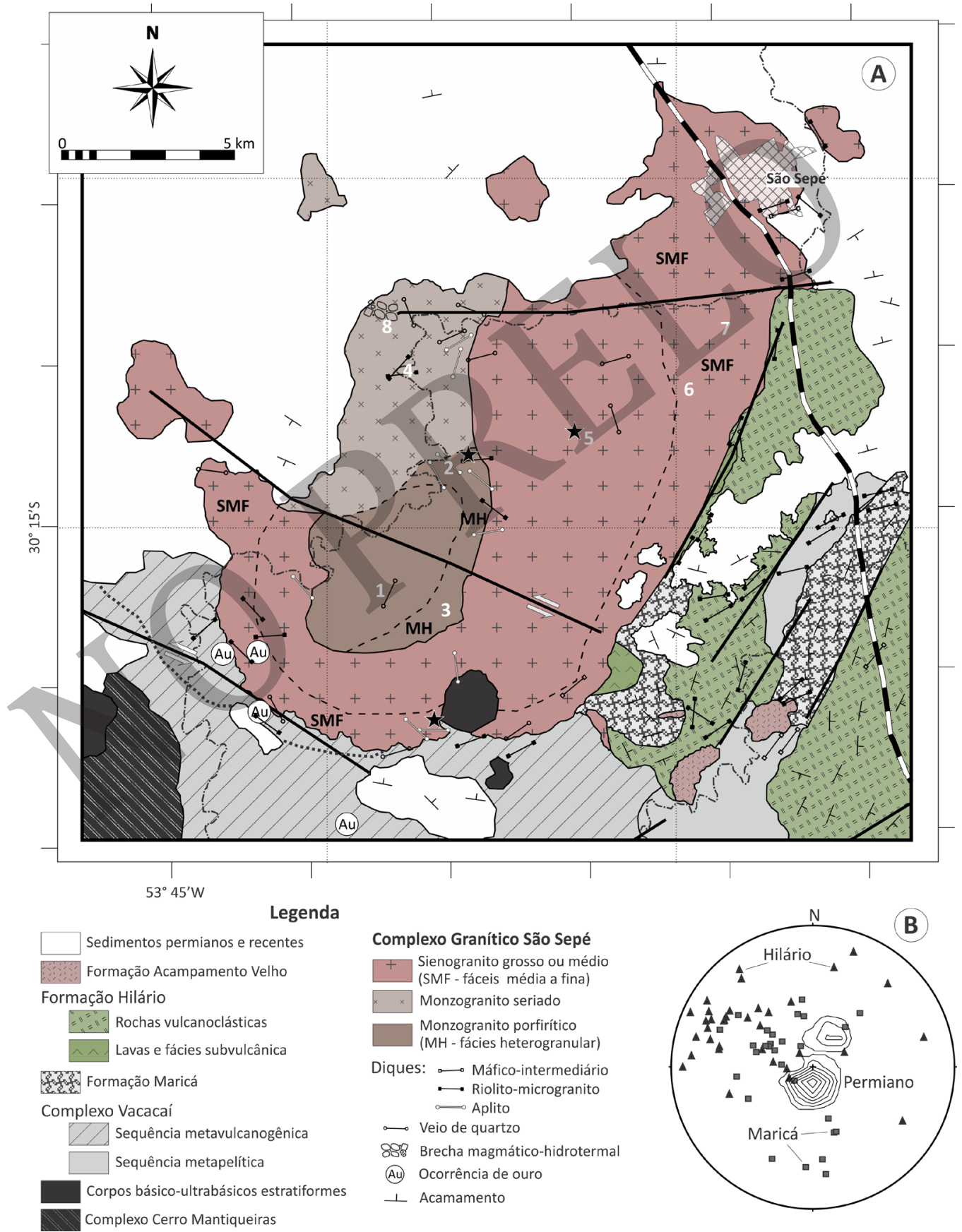

Figura 4. A - Mapa geológico do complexo granítico São Sepé; linhas pretas: tracejada para contato gradativo; pontilhada para zona afetada pelo metamorfismo termal (isógrada da biotita; Matos et al., 2004), cheia e grossa para zonas de falhas (Figs. 1C-D e 8), e tracejada fina para malha de coordenadas UTM, datum Córrego Alegre; drenagem principal sobreposta. Pontos numerados de 1 a 8 localizam os afloramentos, cujas feições petrográficas são mostradas nas figuras 6-7, e estrela marca a localização das amostras datadas pelo método $\mathrm{U}-\mathrm{Pb}$ (veja texto para detalhes); B - Estereograma (rede de Schmidt, hemisfério inferior) para polo de acamamento nas formações basais da Bacia do Camaquã ( $\mathrm{N}$ - Hilário = 35, e Maricá $=28$ ) e naquelas permianas ( $\mathrm{N}=25$, contorno a intervalo de 5\% em 1\% da área) (inclui dados de Aboarrage \& Lopes, 1986; Porcher et al., 1995; UFRGS, 2002). 
rizam o domínio a leste dos complexos graníticos São Sepé (CGSS) e Caçapava do Sul (CGCS), as quais se estendem sob a cobertura permiana a nordeste (Fig. 2A). As anomalias são alongadas e dispostas segundo lineamentos NE-SW a NNW-SSE, equivalentes aos sistemas de falha Santa Bárbara-Cerro dos Cabritos a nordeste, e Angélica-Cerro do Caboclo a leste. Os lineamentos magnéticos são contínuos, retilíneos a sinuosos, com gradientes moderados a altos (Fig. 3). A Z. F. Angélica, a leste, é marcada por anomalia magnética de grande comprimento de onda (5-6 km), corroborando uma estrutura profunda como evidencia o mapa continuado para cima (Fig. 2B). Contudo, esta falha justapõe rochas com propriedades magnéticas muito contrastantes, de modo que poderia corresponder a interface com a sub-bacia Guaritas, cujo depocentro imediatamente a leste é profundo (Kazmierczak, 2006). A anomalia de maior amplitude e grande comprimento de onda (5-6 km), situada no extremo nordeste sob a cobertura paleozóica, é controlada por lineamento magnético $\mathrm{N} 40-45^{\circ} \mathrm{E}$ expressivo e contínuo, que corresponde à extensão norte do sistema Santa Bárbara-Cerro dos Cabritos (Figs. 2-3). Esta anomalia reflete corpo ultramáfico espesso ( $>200 \mathrm{~m}$ de serpentinitos), amostrado em sondagem a $244 \mathrm{~m}$ de profundidade (Ribeiro, 1978). Os lineamentos magnéticos $\mathrm{N} 60-70^{\circ} \mathrm{E}$ nesta região, correlacionáveis à Z. F. Cerro da Cria, são menores, estão expressos por anomalias lineares também em profundidade (Figs. 2B e 3), e são interrompidos e deslocados por aqueles NNE-SSW a NE-SW, como evidenciado em superfície (Fig. 1C). Aqueles de direção N15-20 $\mathrm{E}$ são representados por gradientes lineares que deslocam com movimento direito as anomalias de direção NE-SW (Fig. 3), o que se mantém em profundidade (Fig. 2B). A interseção mútua entre as zonas de falha Santa Bárbara e Cerro dos Cabritos é também evidente nos mapas das derivadas verticais (Fig. 3), a noroeste do CGCS, refletindo sucessivas reativações. O lineamento magnético $\mathrm{N} 30-35^{\circ} \mathrm{E}$ no limite leste do CGSS, parece traduzir uma estrutura profunda como sugerido no mapa continuado (Fig. 2B). Este é deslocado a sul, com movimento esquerdo, por lineamento magnético mais discreto e descontínuo, equivalente à Z. F. Arroio do Engenho (NW-SE, Fig. 3).

As relações expostas nos mapas magnéticos sugerem, assim, que as zonas de falhas $\mathrm{N} 60-70^{\circ} \mathrm{E}$ e N30$-45^{\circ} \mathrm{E}$ estão relacionadas à evolução do embasamento e são verticais a subverticais, dado que os gradientes magnéticos lineares permanecem estacionários nos mapas em que são retirados os sinais de diferentes comprimentos de onda (Figs. 2B-C e 3). Estas foram sucedidas pelas zonas de falhas de direção NW-SE expressas nos dois domínios, e NNE-SSW restritas àquele do leste. Contudo, o sistema Santa Bárbara-Cerro dos Cabritos (NNE-SSW a NE-SW) teria sido reativado mais de uma vez. Os três complexos graníticos, expostos nesta região (CGCS, CGSS e CGR; Fig. 1B), exibem baixa a moderada amplitude do sinal analítico (Fig. 2A). Entretan- to, o sinal magnético positivo no mapa continuado para o CGCS e centro-sul do CGSS poderia ser um indicativo da conexão destes aos sistemas de transferência de magma (Fig. 2B). Nos mapas do gradiente horizontal total (Fig. 2C), e inclinação do sinal analítico (não mostrado), os limites dos dois são realçados, corroborando que o CGSS se estende para norte sob a cobertura permiana.

\section{Complexo granítico São Sepé}

\subsection{Geologia}

O complexo granítico São Sepé (CGSS), com dimensão de $27,0 \mathrm{~km} \mathrm{x} 17,5 \mathrm{~km}\left(\approx 473 \mathrm{~km}^{2}\right)$, é alongado na direção NNE-SSW e tem área aflorante de $180 \mathrm{~km}^{2}$. Está sobreposto a oeste e norte pela Formação Rio Bonito, envolve parcialmente o corpo estratiforme das Pedras Pretas a sul-sudeste, e é intrusivo no Complexo Metamórfico Vacacaí a sudoeste-sul e nas formações Maricá e Hilário a leste (Fig. 4A). A intrusão desenvolveu auréola de metamorfismo termal de baixo a médio grau em rochas da sequência Vacacaí (Matos et al., 2004). A zonação térmica, definida em metapelitos (zonas da biotita, granada e estaurolita), acompanha o contorno do pluton ao longo de uma faixa a sul-sudoeste (Fig. 4A). Os cornubianitos são afetados por evento hidrotermal atribuído à evolução do granito (Porcher et al., 1995), o qual foi responsável pela geração de greisens associados a filões auríferos, também ocorrentes em prospectos inativos no sudoeste do pluton. Entretanto, a gênese da mineralização aurífera é atribuída à remobilização hidrotermal das encaixantes metavulcano-sedimentares, portadoras de jazidas de ouro de médio porte (Remus et al., 1999). Nas encaixantes a leste-sudeste, o efeito termal da intrusão é mais tênue.

0 pluton consiste de granitos texturalmente isotrópicos que exibem zonação composicional reversa, com anfibólio-biotita monzogranitos no centro e biotita sienogranitos na borda (Fig. 4A). 0 contato entre eles, orientado segundo direção N-S a leste e a oeste, é brusco sendo comum matacões e pequenos lajeados dos dois lado a lado, mas sem redução da granulação em nenhum deles. Ambos são secionados por diques de aplitos e microgranitos nas proximidades do contato interno, o que dificulta estabelecer o vínculo genético dessas fácies tardias a qualquer um deles. Intrusões menores, posicionadas preferencialmente a leste e vinculadas ao CGSS, incluem microgranitos diversos, riolito e riodacito, que ocorrem como apófises e diques na borda ou nas encaixantes imediatas (Sartori, 1978; Gastal, 1998). 


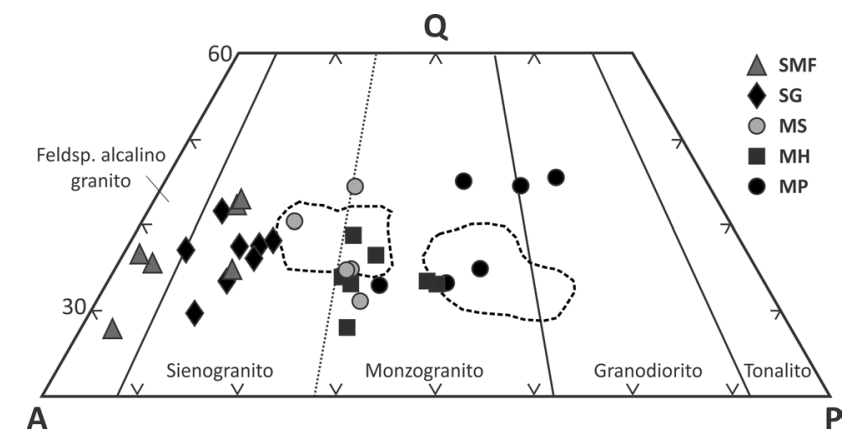

Figura 5. Porção do diagrama QAP para as rochas graníticas (Le Maitre, 2002), exibindo análises modais do complexo granítico São Sepé (modificadas de Gastal, 1998), comparadas às apresentadas por Sartori (1978 - campos delimitados por linha tracejada). Monzogranitos centrais: MP - porfirítico grosso e fino; MH - heterogranular grosso a fino e MS - seriado grosso a médio; e sienogranitos da borda: SG - equigranular grosso ou médio; e SMF - seriado a heterogranular médio a fino ou muito fino, que evolui a feldspato alcalino granito.

\subsection{Grupos de granitos}

\section{Monzogranitos centrais}

Os monzogranitos são divididos em tipos porfirítico grosso e fino (MP) e seriado médio a grosso (MS), situados respectivamente no sul e norte (Fig. 4A). OMP varia até granodiorito (Fig. 5), e grada a sudeste-leste e a nordeste para monzogranito heterogranular grosso a fino (MH). $O$ contato entre MP e MS é gradativo ou marcado pelo MH. No tipo porfirítico (MP; Fig. 6A), a abundância de fenocristais de plagioclásio e K-feldspato tende a aumentar do centro para a borda (10-15\% a 30\%). Grande variação textural caracteriza o MH (Figs. 6BC), que contém porções com predomínio ora de grãos médios ou finos, ora grossos. São comuns segregações poligenéticas $(\mathrm{dm})$, alongadas ou arredondadas, constituídas por grãos grossos de feldspatos, anfibólio e abundantes feições de desequilíbrio (Fig. 6C). Em afloramentos com grande heterogeneidade, ocorrem diques estreitos de microgranito granofírico $(<3-4 \mathrm{~cm})$, com contatos irregulares e difusos (Fig. 6D), e enclaves microgranulares diversos. 0 termo enclave é utilizado como inclusão coeva formada durante interação de magmas máfico e félsico, seguindo Vernon (2004).

Os enclaves maiores (50-30 cm), médios ou finos, variam de granodiorito a quartzo-diorito e exibem contatos irregulares e difusos, ou localizadamente bruscos com o granito envolvente (MH; Figs. 6E-G). Neles, os grãos grossos capturados (K-feldspato e plagioclásio) estão concentrados nas bordas refletindo a maior interação entre os magmas envolvidos. Enclaves de menor dimensão, presentes também nas segregações poligenéticas, incluem variedades médias ou finas, mesocráticas (monzodiorito) e máficas (diorito). Aqueles máficos ocorrem dispersos em microenclaves $(<2-1$ $\mathrm{cm}$ ), no MH e enclave granodiorítico (Figs. 6B, F-G). No monzogranito seriado (MS), homogêneo a escala de afloramento, predominam grãos grossos de K-feldspa- to e quartzo, e as feições de desequilíbrio são menos evidentes. O MS transiciona a sienogranito porfirítico grosso e fino (Fig. 5), comum a oeste do Rio São Sepé. Diques de microgranito e aplito (cm-dm), com contatos regulares a lobados, são comuns. Estes, por vezes, são margeados por schlierens de biotita em uma faixa estreita $(10-20 \mathrm{~cm})$, os quais são secionados por vênulas e/ou bolsões aplíticos com traçados irregulares e curvos (Figs. 6H-I).

\section{Sienogranitos da borda}

Os sienogranitos exibem decréscimo acentuado da granulação no sentido centro-borda, sendo individualizados dois tipos: equigranular grosso/muito grosso ou médio (SG), que é dominante; e heterogranular médio a fino ou muito fino (SMF), que varia até feldspato alcalino granito (Figs. 4A e 5). 0 contato entre eles é gradativo, porém próximo à Z. F. Rio São Sepé, o tipo dominante é secionado por apófises de SMF. 0 sienogranito muito grosso, restrito ao contato com o $\mathrm{MH}$, contém escassos enclaves máficos ( $\mathrm{cm}-\mathrm{dm})$ e plagioclásio saliente. No SG dominante, o plagioclásio é intersticial e o K-feldspato forma agregados de grãos (Fig. 7A).

o SMF constitui uma faixa ao longo da borda do corpo, com largura variando de $0,8-1,0 \mathrm{~km}$ no sul-leste até 5,0-6,0 km no nordeste (Fig. 3A). Esta fácies, interpretada como margem resfriada félsica, é muito heterogênea em afloramento, contém cavidades miarolíticas dispersas (mm-cm; Fig. 7B), e é secionada por aplitos e microgranitos (sul-leste). As cavidades miarolíticas preenchidas por K-feldspato e quartzo ( \pm biotita), de dimensões variadas $(<1-2 \mathrm{~cm}$ até 40-50 $\mathrm{cm})$, possuem formas arredondadas, irregulares ou em tubos verticais. No norte-nordeste, onde esta faixa de SMF é ampliada, as cavidades são abundantes e ocorrem bolsões de feldspato alcalino granito (hm-km), com contatos gradativos ou bruscos com o SMF. Estes, considerados como parte da cúpula granítica, exibem textura miarolítica interconectada. Tal textura consiste em uma rede anastomosada de cavidades miarolíticas e segregações micropegmatíticas (= miarolas; Candela \& Blevin, 1995), interconectadas e envoltas pela matriz aplítica (Figs. 7C-E). Os grãos de quartzo e K-feldspato, com formas euédricas e extensões box-celular (Fig. 7D), nucleiam a partir do invólucro aplítico para o interior em decorrência do acúmulo de voláteis. As texturas na matriz aplítica consistem de zonas alongadas de miarolas finas separadas por intercrescimentos granofíricos e micrográficos (Fig. 7E). Registram, assim, condições variadas de subresfriamento (undercooling), que representa o quanto a temperatura de cristalização é reduzida abaixo da liquidus devido ao desequilíbrio gerado pela perda abrupta de calor, supersaturação do magma em constituintes, descompressão e/ou desvolatilização.

A brecha magmático-hidrotermal, associada à apófise de SMF, forma um corpo alongado ( $150 \mathrm{~m} \mathrm{x}$ 

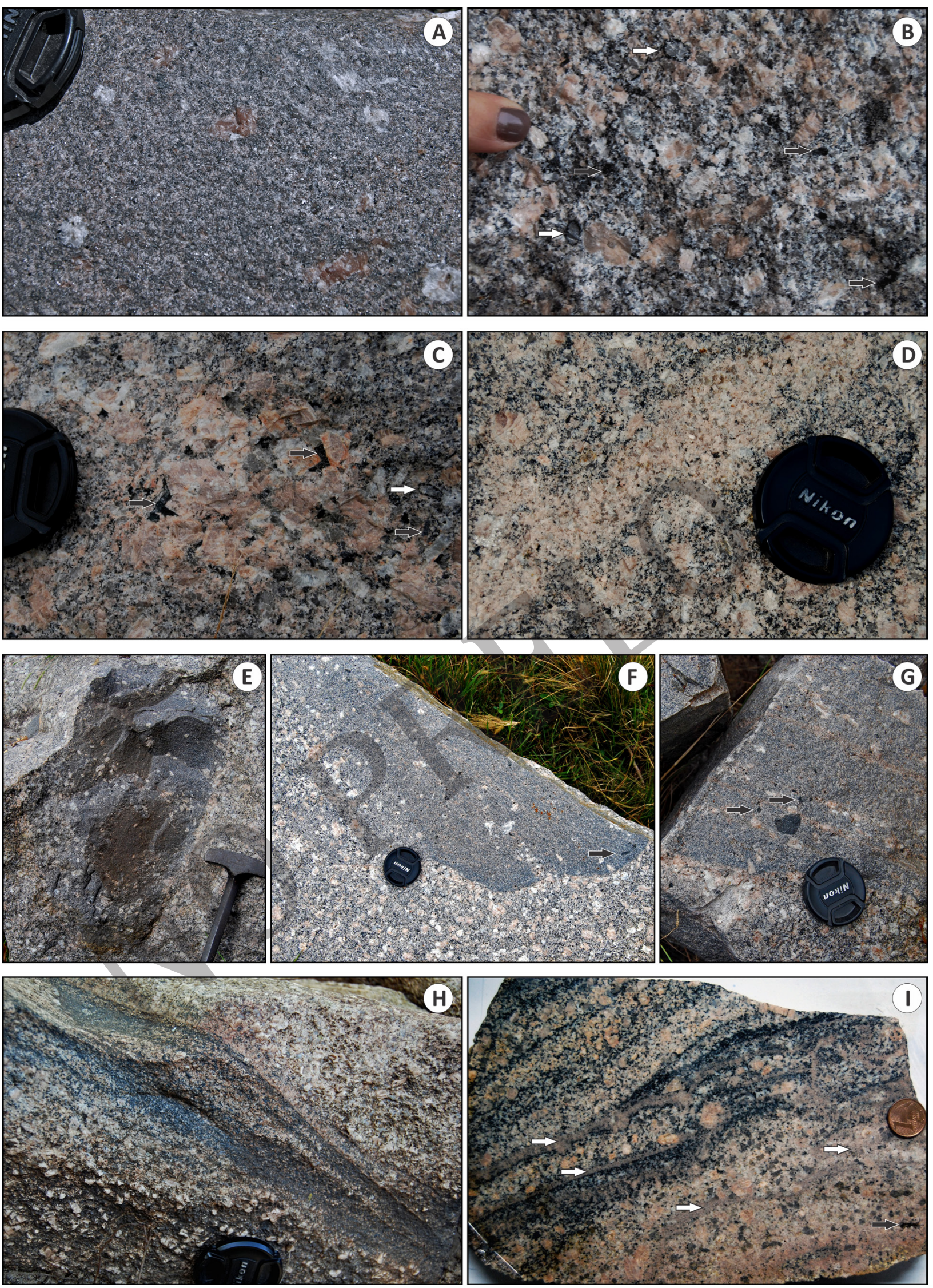

Figura 6. Fotografias - monzogranitos centrais: A - Porfirítico (MP), com escassos fenocristais grossos de plagioclásio e K-feldspato, e matriz fina; B - Heterogranular (MH), com ocelos de quartzo (seta branca), textura rapakivi e microenclaves máficos (seta preta); C - Segregação poligenética no $\mathrm{MH}$, grãos grossos de feldspatos e anfibólio (seta preta), e feições de desequilíbrio abundantes (seta branca para ocelo de quartzo); D - Dique de microgranito granofírico, contato irregular e difuso com o $\mathrm{MH}$ ( $<3 \mathrm{~cm}$ de espessura); E-G - Enclaves granodiorítico a quartzo-diorítico $(\mathrm{dm})$ no $\mathrm{MH}$, com contato brusco e fenocristais de feldspatos concentrados na borda e em faixa central (E); contato variando de brusco a gradativo (F); inclusão de microenclaves máficos (seta preta em F-G), e vênulas graníticas (G); H-I - Bandamento composicional, associado a vênulas de aplito, no monzogranito seriado (MS): H - Schlierens irregulares de biotita, em afloramento; I - Amostra com schlierens recortados por vênulas de aplito ( $\mathrm{mm}$ ) regulares a irregulares (seta branca), concentradas na porção central leucocrática (seta preta para microcavidade miarolítica). Localização dos afloramentos na figura 4A: 1 - A; 2 - B e E; 3 - C-D e F-G; 4 - H-I (diâmetro de 5,5 cm - tampa da lente; e 1,6 cm - moeda em I). 

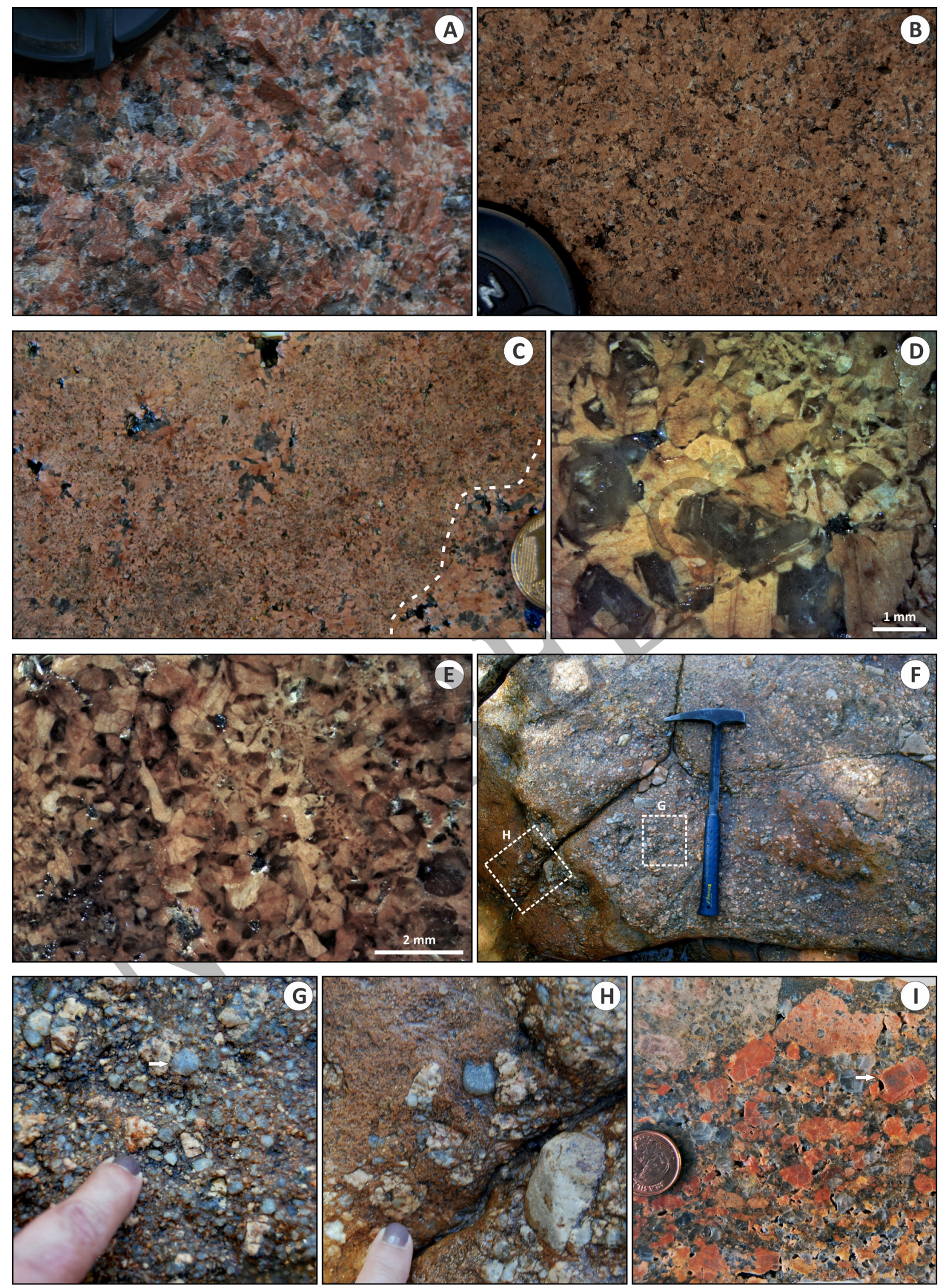

Figura 7. Fotografias - sienogranito da borda e rochas associadas: A - Sienogranito equigranular grosso dominante (SG); B - Sienogranito seriado médio a fino (SMF), com cavidades miarolíticas finas $(\mathrm{mm}-\mathrm{cm})$; C -feldspato alcalino granito médio a fino, com textura miarolítica interconectada; linha branca tracejada realça o contato com o SMF; D - Bolsões micropegmatíticos em C, cristais euédricos com formas regulares ou box-celular, e crescimento orientado de K-feldspato em quartzo (textura snow-ball); E - Fração fina em C, grãos finos anédricos e intercrescimentos granofíricos circundando núcleos mais cristalinos; F - Brecha magmático-hidrotermal, em afloramento, consistindo de porções com grânulos e seixos subangulosos a subarredondados de quartzo, K-feldspato e fácies subvulcânicas, e outras com matriz aplítica (esquerda); G - Detalhe da fração clasto suportada (seta branca para quartzo euédrico); H - Detalhe da fração com matriz aplítica contendo clastos subarredondados de SG e fácies hipoabissal; e I - Amostra da brecha granítica (seta branca para grão subédrico de K-feldspato), com fragmentos de riolito e vugs de quartzo. Localização dos afloramentos na figura 3A: 5 - A; 6 - B; 7 - C-E; 8 - F-I (escalas como na figura 6 ). 
$15 \mathrm{~m}$ ), cuja extensão real é difícil de dimensionar dada a cobertura parcial dos sedimentos permianos (Fig. $4 \mathrm{~A})$. Esta é constituída por granito com grãos médios ou grossos intensamente quebrados, contendo bandas irregulares de brecha clasto suportada alternadas a zonas de matriz aplítica (Figs. 7F-I). Os clastos incluem grânulos, seixos e raros blocos, subangulosos e subarredondados, de quartzo (grãos e fragmentos de veios bandados), K-feldspato e fragmentos de sienogranito grosso, microgranito e fácies hipoabissais.

\subsection{Considerações sobre a geocronologia}

A proposição de corpos intrusivos distintos para o CGSS foi também impulsionada pelo intervalo de, pelo menos, 20 m.a. entre os dois grupos de granitos sugerido pelas idades $\mathrm{Rb}-\mathrm{Sr}$ em rocha total (RT; Soliani Jr., 1986): $669 \pm 108 \mathrm{Ma}-$ monzogranitos centrais, e 527 $\pm 14 \mathrm{Ma}$ - sienogranitos da borda (todas a $2 \sigma$ ). Para as intrusões menores periféricas, o autor obtém a idade $\mathrm{Rb}$-Sr (RT) de $466 \pm 12 \mathrm{Ma}$, contudo Vlach \& Cordani (1986) ressaltam que tais idades muito mais jovens podem refletir distúrbios no sistema isotópico $\mathrm{Rb}-\mathrm{Sr}$ decorrentes da cristalização fracionada prolongada ou de eventos hidrotermais. Gastal \& Lafon (1998), com base na idade ${ }^{207} \mathrm{~Pb} /{ }^{206} \mathrm{~Pb}$ mais jovem obtida em zircões de uma amostra de monzogranito heterogranular, sugerem que a idade $\mathrm{Rb}-\mathrm{Sr}$ de $669 \pm 108 \mathrm{Ma}$ representa uma linha de mistura. Todavia, os resultados obtidos não são conclusivos ( $525 \pm 40$ Ma ou $555 \pm 31 \mathrm{Ma}, 2 \sigma)$.

A proximidade temporal entre os granitos é confirmada com as idades U-Pb (SHRIMP) obtidas em zircões (Remus et al., 1999), para uma amostra de monzogranito heterogranular - 558,9 $\pm 4 \mathrm{Ma}(\mathrm{MSWD}=0,25$; 22 spots; $2 \sigma$ ), e outra de microgranito da borda $-554,3$ $\pm 4,3$ Ma (MSWD $=0,11 ; 7$ spots; $2 \sigma$ ). Os valores para estas idades foram recalculados descartando os spots discordantes, o que não altera o significado, qual seja, não é possível estabelecer um intervalo de tempo entre a formação dos granitos mais contrastantes. Gastal et al. (2010), ao reinterpretarem estes dados, observam populações de idades similares nas duas amostras, sugerindo ciclos intrusivos a 568-566 Ma e 550-544 Ma. Os autores obtém uma idade preliminar U-Pb (LA-ICPMS) de 539,1 \pm 6,5 Ma (MSWD = 4,2; 6 spots; $2 \sigma$ ), em zircões de uma amostra de sienogranito grosso. Os zircões exibem núcleos manchados e corroídos, com embaiamentos preenchidos por xenotima/monazita. Em virtude da interpretação de que as idades $\mathrm{U}-\mathrm{Pb}$ mais jovens $(<550 \mathrm{Ma})$ decorrem da remobilização do zircão em evento hidrotermal tardio, assumimos a idade de ca. 567 Ma para a formação do CGSS (amostras com idades U-Pb localizadas na figura 4A).

Com base na compilação de idades U-Pb para rochas do evento ígneo do final do Neoproterozóico na região, Gastal et al. (2010) observam a mesma dualidade nas idades, qual seja: $573 \pm 18$ Ma e $548 \pm 4$ Ma para vulcânicas, respectivamente, dos cerros do Perau-Bu- gio e Platô da Ramada (CBP e PR, Fig. 1B; F. Chemale Jr., comunicação oral; Sommer et al., 2005), e duas populações de idades, 564-562 Ma e 545 Ma, em amostras do complexo granítico Caçapava do Sul (CGCS; Remus et al., 2000). Tal dualidade nas idades U-Pb, como ressaltam os autores, tem implicações importantes quanto ao entendimento deste evento ígneo, se formado num curto intervalo de tempo (575-560 Ma), ou em episódios distintos (575-560 Ma e 550-535 Ma).

\subsection{Estruturas rúpteis}

Dentre os alinhamentos nas imediações do CGSS, detalhados na imagem ASTER (Fig. 8), sobressaem aqueles de direção $\mathrm{N} 55-60^{\circ} \mathrm{E}\left(\mathrm{N} 70^{\circ} \mathrm{E}\right), \mathrm{N}^{\circ} 0^{\circ} \mathrm{E}(\mathrm{N} 25-$ $-30^{\circ} \mathrm{E}$ ) e $\mathrm{N} 50-65^{\circ} \mathrm{W}$, sendo os dois últimos relacionados a zonas de falha regionais que condicionam os contatos leste e sudoeste-sul do pluton. Aqueles de direção N60$-70^{\circ}$ E são marcantes em unidades do arco magmático e parte da Formação Hilário situada no extremo sudeste, ao passo que na porção centro-oeste do CGSS predomina as direções $\mathrm{N} 50-55^{\circ} \mathrm{E}$. Esses são alinhamentos mais curtos e interrompidos pelos de direção NW-SE, os quais afetam preferencialmente os monzogranitos. Fraturamento mais intenso ao longo da borda do pluton ocorre segundo as duas outras direções $\left(\mathrm{N} 40\right.$ a $25^{\circ} \mathrm{E}$ e $\mathrm{N} 50-65^{\circ} \mathrm{W}$ ), todavia a presença de ampla margem resfriada félsica descarta contatos tectônicos (Figs. 4A e 8). No leste, diques de composições variadas ocorrem na margem félsica e encaixantes imediatas $\left(\mathrm{N} 40^{\circ} \mathrm{E}\right.$ a NNE-SSW). Isto, aliado à presença de rochas efusivas e subvulcânicas da Formação Hilário (Fig. 4A), corrobora que o contato leste é condicionado por estrutura profunda, de direção $\mathrm{N} 30-35^{\circ} \mathrm{E}$, que serviu de conduto para magmas diversos. 0 sistema $\mathrm{N} 50-65^{\circ} \mathrm{W}$ é representado por dois lineamentos tectônicos, que variam até $\mathrm{N} 30-40^{\circ} \mathrm{W}$ para oeste: a Z. F. Arroio do Engenho a sul e outro no centro-sul do complexo granítico. Segundo esta direção ocorrem fraturas contínuas, regulares e espaçadas na margem félsica, e zonas de cataclase discretas e estreitas ( $\mathrm{cm}$ a dm) nos sienogranitos grossos e monzogranitos. Os lineamentos de direção N35-30 ${ }^{\circ} \mathrm{E}$, nas encaixantes a leste, são interrompidos pelos de direção NW-SE. Estas duas direções controlam o contato entre a fácies de borda e o corpo básico-ultrabásico Pedras Pretas (Fig. 8). Além disso, rotação e basculamento de camadas das formações Hilário e Maricá, e em menor intensidade da cobertura permiana, ocorrem próximo à interseção destes lineamentos (Figs. 4A-B).

Os alinhamentos N70-80 $\mathrm{W}$ (a N75-85 ${ }^{\circ}$ ) são significativos na porção central do CGSS, em especial, nas imediações da Z. F. Rio São Sepé de mesma direção (Fig. 8B). O sistema WNW-ESE é caracterizado por fraturamento mais intenso, zonas estreitas de cataclase associadas a diques de aplito $(\mathrm{dm}$ a $\mathrm{cm})$, veios de quartzo e brecha magmático-hidrotermal nos monzogranitos, e incipiente cataclase nos sienogranitos. Entretanto, no interior do pluton, não foram encontrados planos de 


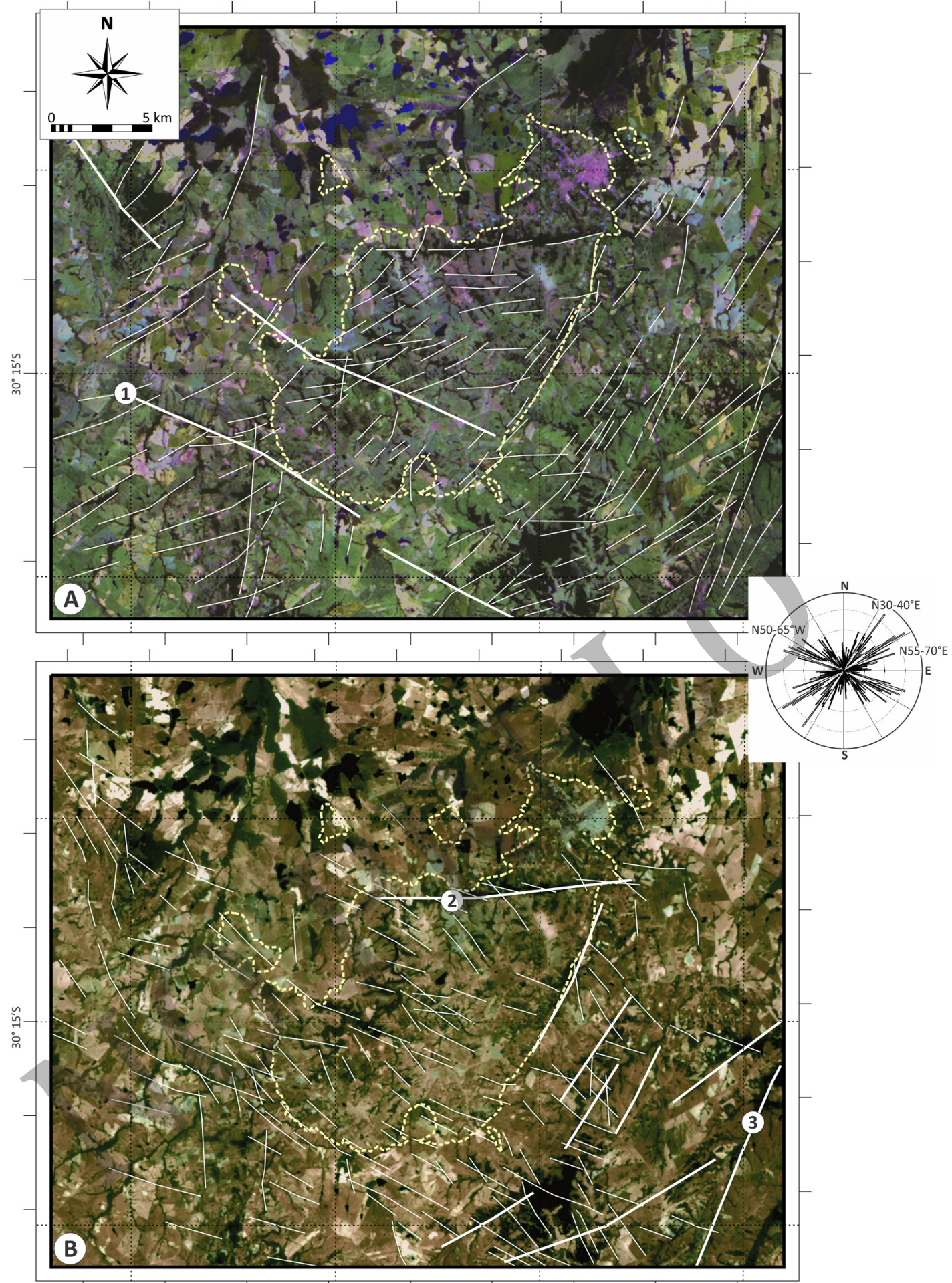

Figura 8. Composições coloridas da imagem ASTER: A - RGB 742 (VNIR-SWIR); B - RGB 456 (SWIR), exibindo alinhamentos e lineamentos tectônicos (traços brancos finos e grossos, respectivamente), para a região do complexo granítico São Sepé (contorno realçado por linha pontilhada grossa). Zona de falhas: 1 - Arroio do Engenho, 2 - Rio São Sepé e 3 - Santa Bárbara; diagrama de rosetas para alinhamentos (círculos internos a intervalo de $5 \mathrm{~km}$; N - NE-SW = $497 \mathrm{~km}$, e NW-SE = $396 \mathrm{~km}$ ). Malha de coordenadas UTM como na figura 4.

falha estriados, ou outros indicadores cinemáticos confiáveis que permitam a análise destas estruturas.

\section{Petrografia}

\subsection{Monzogranitos centrais}

A mineralogia nos monzogranitos inclui oligoclásio $\left(\mathrm{An}_{30-12}\right)$, ortoclásio (determinado pela triclinicida- de; Gastal, 1998), anfibólio (Fe-hornblenda a Fe-edenita), e Fe-biotita. Como acessórios ocorrem zircão, titanita, alanita, magnetita-ilmenita e apatita. Agregados de grãos de plagioclásio e anfibólio, e a substituição tardi-magmática do anfibólio por biotita e titanita são feições comuns. Nos monzogranitos porfiríticos e heterogranulares (MP-MH), com similar conteúdo de máficos (6-10\%), o anfibólio é significativo (2-4\%) e o plagioclásio varia até andesina $\left(\mathrm{An}_{32-40}\right)$, enquanto a biotita é amplamente dominante (3-10\%) no monzo- 
granito seriado (MS; 4-12\% de máficos).

O MP menos evoluído contém escassos fenocristais $(<10-15 \%)$ e maior percentual de plagioclásio, porém elevado quartzo (Fig. 5). Este ocorre em grãos intersticiais poiquilíticos envolvendo grãos finos de anfibólio e plagioclásio, subédricos a euédricos, por vezes corroídos (Figs. 9A-B). Esta textura registra dois momentos na cristalização durante a interação de magmas contrastantes (mixing parcial): minerais precoces e finos que representam a cristalização da fração máfica devido ao subresfriamento termal; e aqueles tardios cristalizados a partir do líquido residual hibridizado, após o equilíbrio termal das frações máfica e félsica (Vernon, 2004). Feições similares ocorrem nos enclaves mais máficos (Figs. 9C-D), ao passo que grãos finos e anédricos de quartzo e K-feldspato distribuídos homogeneamente naqueles granodioríticos sugerem cristalização a partir de magma previamente hibridizado (Fig. 9E). 0 anfibólio em grãos subédricos, com núcleos ocasionais de clinopiroxênio (Fig. 9F), indica hidratação precoce na cristalização do $\mathrm{MH}$, o qual se caracteriza pela diversidade de feições de desequilíbrio termal e composicional. Tais registros incluem: (a) feições superficiais como arredondamento (Figs. 9C e E, e 10J), e embaiamento de grãos ou de núcleos cálcicos no plagioclásio (Figs. 9A, e 10D e F); (b) manteamentos como ocelos de quartzo (Figs. 9G-H), e rapakivi (Figs. 9C e E; e 10A-C); e (c) feições pervasivas como textu ras celulares de grãos ou núcleos de plagioclásio (Figs. 10E-I). Nas segregações poligenéticas (MH; Fig. 6C), estão concentrados manteamentos, morfologias celulares e agregados de plagioclásio com zonações complexas, spikes cálcicos, e relação de synneusis incluindo grãos com composições e texturas distintas (Figs.10D-F). As texturas celulares do plagioclásio são comuns e os manteamentos ocasionais no MS (Figs. 10B-C).

Os ocelos incluem um grão ou agregado de poucos grãos de quartzo, envoltos por manto disperso de grãos finos de biotita e anfibólio ( \pm óxidos de Fe-Ti e titanita). 0 quartzo exibe incipiente embaiamento, extinção ondulante e sobrecrescimento epitaxial intercrescido com o manto máfico ( \pm K-feldspato). Tais sobrecrescimentos nos ocelos, comuns no cenário de mistura de magmas, indicam a retomada da cristalização após curto período de suspensão (Hibbard, 1995; Vernon, 2004). A dissolução do K-feldspato, com formação da textura rapakivi, é um processo incongruente controlado pelas taxas de difusão química. Estas taxas, ao estabelecerem gradientes químicos no magma adjacente, favorecem a cristalização do plagioclásio ao longo de condutos de dissolução constituindo zonas de reação com aspecto manchado (Figs. 9C e 10A), ou morfologias box-celular (Wark \& Stimac, 1992). A aderência mecânica de grãos de plagioclásio ao redor do K-feldspato, citada como mecanismo auxiliar na formação da rapakivi (Hibbard, 1995), poderia explicar algumas feições no MS (Fig. 10B). Em condições plutônicas, o crescimento das morfologias celulares preenchidas ou intercrescidas com quartzo e grãos finos de biotita ( \pm anfibólio), no manto de plagioclásio, é favorecido (coarsening). A completa dissolução do K-feldspato gera plagioclásio celular com aspecto quadriculado (Fig. 10E), dado pelos domínios retangulares de oligoclásio/andesina em uma matriz mais sódica, ou então, células irregulares ou vênulas de plagioclásio mais cálcico (Hibbard, 1995). Denominamos de plagioclásio rendilhado este tipo de textura celular, comum no MH e MS (Figs. 10G-I). A presença de restos/manchas de K-feldspato (quartzo e máficos), em alguns destes grãos, permite interpretá-los como K-feldspato dissolvido (Figs. 10H-I). Entretanto, outros poderiam ser atribuídos à dissolução do plagioclásio por superaquecimento, esperada em oligoclásio capturado pelo magma máfico (Fig. 10G).

No MS, o K-feldspato sobrecrescido ao redor de rapakivi envolve e parcialmente desmembra o manto de plagioclásio (Fig. 10C), que resta como manchas irregulares. Estas manchas com composição $\mathrm{An}_{15-24}$, denominadas de pseudo-pertitas (Sartori, 1978), são frequentes nesta fácies. Isto sugere a reabsorção do manto de plagioclásio ocasionada por novo pulso de magma félsico, ou a recaptura por esse magma de K-feldspato previamente dissolvido.

\subsection{Sienogranitos da borda}

$\mathrm{O}$ sienogranito equigranular (SG) exibe mineralogia próxima a do monzogranito mais evoluído (MS), com oligoclásio-albita $\left(\mathrm{An}_{27-9}\right)$ e Fe-biotita dominante (7-2\%), diferindo pela presença de fluorita intersticial e maior abundância da albita tardia. 0 K-feldspato varia de ortoclásio a microclínio intermediário (Gastal, 1998), exibindo pertitas em veios, e manchas de oligoclásio (pseudo-pertitas) indicativas de reabsorção. Agregados de grãos de plagioclásio e biotita $( \pm \mathrm{Fe}-$ -edenita e óxidos Fe-Ti), e quartzo com embaiamentos e forte extinção ondulante são comuns no SG menos evoluído, no qual grãos grossos a muito grossos de plagioclásio rendilhado são ocasionais (Fig. 10J). Estes exibem sinais de uma história mais prolongada, tais como arredondamento dos grãos, intercrescimentos de quartzo e inclusões anédricas de plagioclásio cálcico e de biotita e anfibólio, que são abundantes e marcam linhas de crescimento.

No sienogranito médio a fino (SFM), a biotita é escassa $(<2,5 \%)$, o plagioclásio varia de oligoclásio sódico a albita, e a fluorita é abundante. Variações texturais relacionadas à frequência de miarolas definem dois extremos: (1) aqueles com agregados de K-feldspato e quartzo, com extensões esqueletais incipientes, arranjos análogos ao SG, e transformações pós-magmáticas significativas (pertitas em veios e manchas, e maior abundância de albita tardia, clorita, mica branca e óxidos de Fe-Ti secundários); e (2) aqueles com miarolas, em que tais transformações são inexpressivas e os grãos esqueletais de quartzo e K-feldspato evoluem a intercrescimentos micrográfico e granofírico. 0 fato 

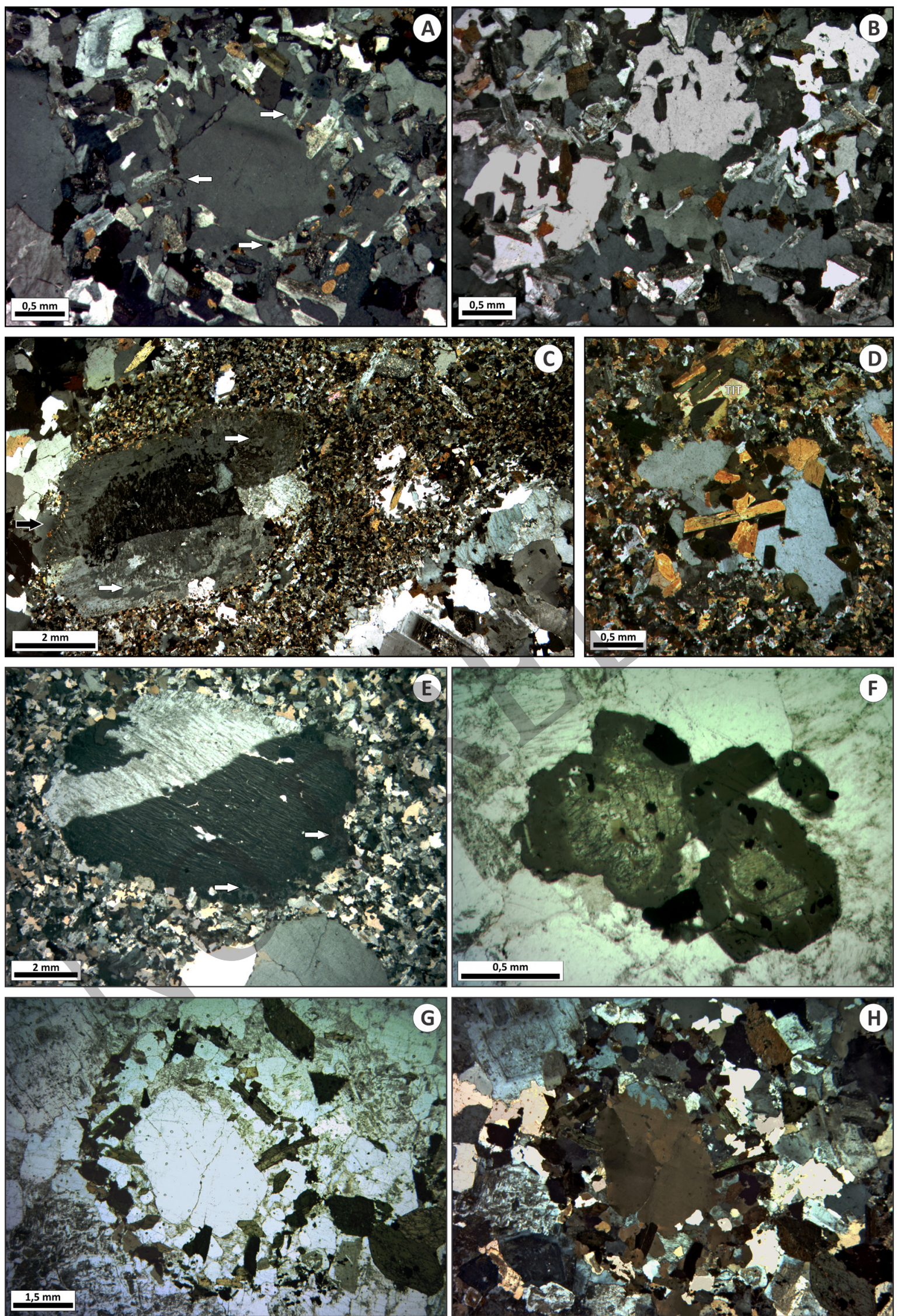

Figura 9. Fotomicrografias - monzogranitos: A-B - Quartzo intersticial e poiquilítico, tipo menos evoluído de monzogranito porfirítico (MP), com inclusões de plagioclásio e anfibólio, subédricos a euédricos ( \pm biotita; luz com polarização cruzada - LXP): A - Inclusões na borda do grão (setas bancas para plagioclásio corroído); B - Agregado de grãos em mosaico; C - Enclave diorítico no monzogranito heterogranular (MH; LXP), granulação fina a base de hornblenda ( \pm biotita) e plagioclásio; bolsões de quartzo tardio poiquilítico; e grão de K-feldspato (Kfs) capturado e parcialmente dissolvido, exibindo textura rapakivi e sobrecrescimento de plagioclásio sódico no lado do granito, separado por trilha de máficos (setas branca e preta, respectivamente); D - Bolsões com quartzo tardio em C, com inclusões de anfibólios médios (TIT - titanita; LXP); E - Enclave granodiorito (MH; LXP), com matriz fina e anédrica e grãos grossos de Kfs e quartzo, capturados e arrendondados (seta branca para incipiente dissolução no Kfs); F - Hornblenda com núcleos de clinopiroxênio (MH; luz plano paralela - LPP); G-H - Ocelo de quartzo (MH; LPP e LXP, respectivamente): grão de quartzo arredondado, com incipiente embaiamento, extinção ondulante e sobrecrescimento epitaxial, intercrescido com Kfs e máficos (anfibólio \pm biotita). 

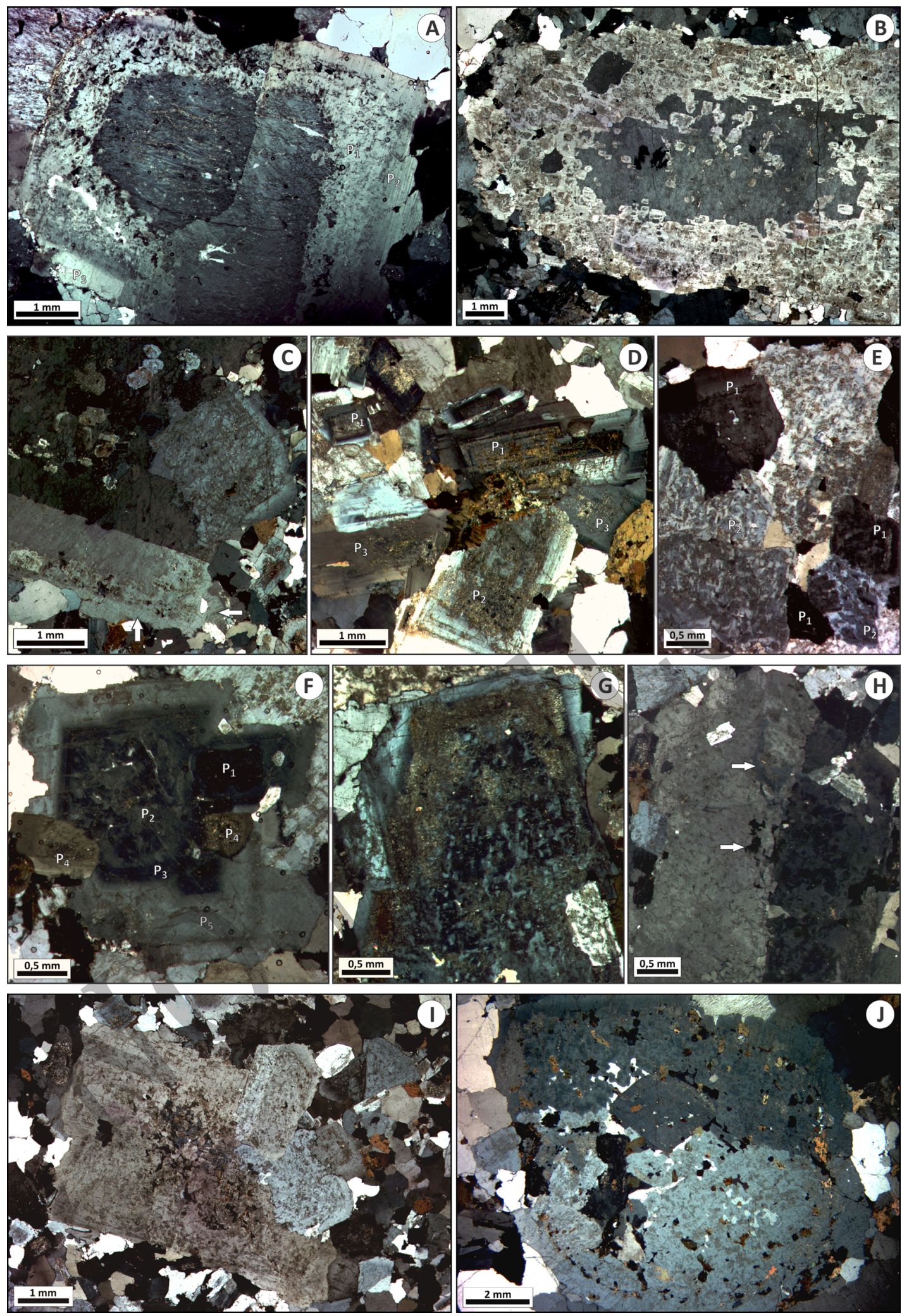

Figura 10. Fotomicrografias - texturas dos feldspatos (LXP): A-C - Textura Rapakivi: A - Extinção ondulante, $\mathrm{P}_{1}$ - plagioclásio (pl) em zona de reação com K-feldspato (Kfs), intercrescido com quartzo; e $\mathrm{P}_{2}-\mathrm{P}_{3}$ - manto parcial de plagioclásio com contato gradativo ( $\mathrm{P}_{2}-$ pl intermediário, fraca zonação normal e borda corroída), ou brusco ( $\mathrm{P}_{3}$ - borda sódica) $(\mathrm{MH})$; B - Adesão mecânica aparente de grãos finos e subédricos de pl (núcleos cálcicos), ao redor do Kfs (monzogranito seriado - MS); C - Agregado de grãos de K-feldspato (MS), com inclusões subédricas e envolto por manto parcial de plagioclásio, e sobrecrescimento tardio de K-feldspato (seta branca); D-F - Agregados de plagioclásio $(\mathrm{MH})$ : D - Associado a hornblenda, $\mathrm{P}_{1}$ - núcleo subédrico, envolto por spike cálcico e borda sódica parcialmente corroída; $\mathrm{P}_{2}$ e $\mathrm{P}_{3}$ - pl intermediário a sódico $\left(\mathrm{P}_{2}\right.$ - núcleo amplo, zonação oscilatória ocasional e borda albítica anédrica, e $\mathrm{P}_{3}$ - zonação incipiente realçada pela alteração); E - Grãos com composição e textura distintas: $\mathrm{P}_{1}$ - pl cálcico, núcleo anédrico manchado envolto por spike cálcico, e borda zonada; $\mathrm{P}_{2}$ - pl intermediário a sódico, com zonação em manchas box-celular e intercrescido com quartzo; $\mathrm{F}$ - Grãos distintos em synneusis: $\mathrm{P}_{1}$ - núcleo cálcico corroído na borda; $\mathrm{P}_{2}$ - núcleo manchado; $\mathrm{P}_{3}$ - spike cálcico com zonação oscilatória fina; $\mathrm{P}_{4}-\mathrm{P}_{5}-\mathrm{pl}$ intermediário ( $\mathrm{P}_{4}$ - zonação normal realçada pela alteração, e $\mathrm{P}_{5}$ - zonação incipiente e borda anédrica); G-J - Plagioclásio rendilhado (G-I - MH, e J no sienogranito muito grosso - SG menos evoluído), intercrescido com quartzo e contendo restos de Kfs (seta branca em H) e inclusões de plagioclásio, envoltos por mantos de pl limpo: $\mathrm{G}$ - Rendilhado geométrico ( $\approx$ box-celular), e manto de pl zonado; $\mathrm{H}$ - Rendilhado irregular e arredondado ( $\approx$ spongy-celular); I - Rendilhado irregular e inclusões finas de máficos; e J - Agregado arredondado de grãos anédricos, com quartzo intercrescido mais desenvolvido e abundantes inclusões de máficos (restos de Kfs não visíveis). 
dos dois tipos ocorrerem no mesmo afloramento evidencia o comportamento irregular da fase volátil magmática.

\subsection{Brecha magmático-hidrotermal}

A brecha magmático-hidrotermal não exibe fraturamento pervasivo ou orientação sistemática. Inclui uma fração mal selecionada, com relação clastos/matriz variada e clastos subarredondados (seixos e blocos) de rochas vinculadas ao CGSS (Figs. 7F-H). Na fração granítica, os litoclastos subarredondados são escassos (Fig. 7I), a matriz aplítica ocorre em quantidades variadas, e o cimento hidrotermal inclui abundantes vugs de quartzo (Figs. 11A-B). A matriz aplítica é composta por quartzo e albita ( \pm Kfs e rara biotita), misturados a quantidades variadas de clastos cominuídos na forma de fragmentos/lascas angulosos (Figs. 11C-E), e farinha de rocha subordinada (Fig. 11F). Nas frações em que a matriz é escassa ou ausente, prevalece a textura granítica e o cimento hidrotermal ocorre entre os grãos, como preenchimento de golfos de corrosão (Fig. 11A), ou agregando fragmentos de grãos (Fig. 11B). Os grânulos de feldspatos e quartzo, por vezes, estão intensamente quebrados sem deslocamento significativo, resultando em textura do tipo jig-saw (Fig. 11D). As fraturas são sempre intragranulares (microcracks; Fig. 11E), mesmo onde o quartzo exibe deformação intracristalina mais intensa (Figs. 11B e F). Todas estas feições corroboram a classificação desta brecha como magmático-hidrotermal, segundo Sillitoe (1985).
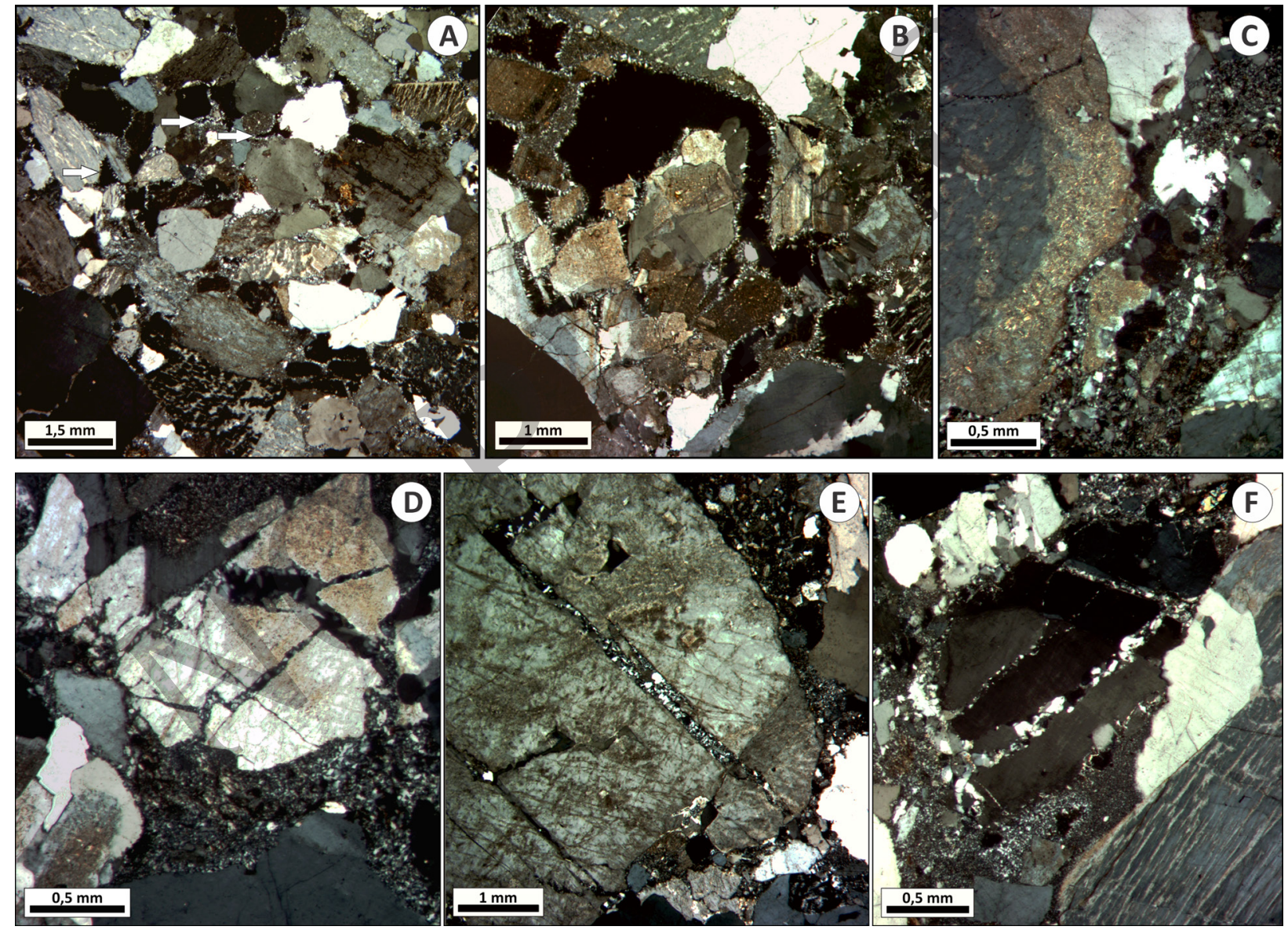

Figura 11. Fotomicrografias - brecha magmático-hidrotermal (Fig. 7I; LXP): A - Porção granítica, sem fraturas, com matriz aplítica rara e vugs de quartzo entre os cristais, ou em golfos de corrosão (seta branca); B - Vugs de quartzo desenvolvidos, cimentando fragmentos de plagioclásio ( \pm quartzo); quartzo, em locais, com forte extinção ondulante; matriz escassa; C - Matriz aplítica, ao lado de rapakivi, constituída por quartzo e albita ( \pm Kfs) e com fragmentos/lascas angulosos dos grãos adjacentes; D - Grão de plagioclásio zonado e quebrado, com textura tipo jig-saw, fraturas preenchidas por aplito e vugs de quartzo; matriz aplítica com poucos grãos cominuidos; E - K-feldpspato com microcracks preenchidos por material similar ao anterior, e matriz aplítica rica em fragmentos angulosos; e F - Grão de quartzo com forte extinção ondulante (subgrãos localizados); microcracks mais largos preenchidos com quartzo e albita, e finos com incipiente recristalização dinâmica do tipo bulging (Passchier \& Trouw, 2005); matriz incluindo aplito e farinha de rocha. 


\section{Discussão}

\subsection{Interação de magmas e a formação da cúpula graní- tica félsica}

Características como delimitação geográfica bem definida, e relações de contato sem evidências claras de intrusão entre monzogranitos centrais e sienogranitos grossos apontam que o CGSS representa um pluton múltiplo ou composto. Tal ideia é corroborada pela proximidade nas idades U-Pb (568 - $566 \mathrm{Ma}$ ), e coerência nas composições litogeoquímicas e mineralógicas (Sartori, 1978; Gastal, 1998). A diferença marcante entre os dois, registradas pelas texturas e estruturas, traduz o predomínio de um dos dois processos de diferenciação magmática: hibridismo nos monzogranitos e extensivo fracionamento mineral nos sienogranitos. Tais diferenças podem ser compatibilizadas em uma intrusão multicíclica, de modo que não tem sentido o uso de denominações distintas para os granitos, como proposto por Porcher et al. (1995).

\section{Monzogranitos centrais - Interação múltipla de mag- mas máfico-félsico}

Os monzogranitos possuem composições próximas e texturas que registram hibridismo diversificado (mixing-mingling). No monzogranito porfirítico (MP), predominou o mixing parcial entre um magma máfico (basáltico) e o granítico como sugerem as texturas do quartzo (Figs. 10A-B). Tais feições implicam que a interação ocorreu em magma granítico parcialmente cristalino $(\leq 30-40 \%$ de cristais; Fernandez \& Barbarin, 1991), o que explica o aumento nos percentuais de fenocristais no sentido centro-borda. As segregações poligenéticas corroboram que o tipo heterogranular (MH) representa uma interface (front de solidificação; Marsh, 2000), em que o mush cristalino foi repetidamente remobilizado com recarga máfica. Assim, a flutuação no comportamento reológico do magma residente possibilitou a preservação e segregação de minerais produzidos em diferentes episódios da mistura. Em interfaces como esta, acima da zona de interação, é esperada a concentração de voláteis devido ao subresfriamento termal do magma máfico, que acelera o fracionamento (Bateman, 1995; Harper et al., 2004; Miller et al., 2011). Estes são sítios favoráveis à segregação e extração de líquidos magmáticos residuais, via processos de compactação do mush cristalino ou filter pressing, cujos resultados seriam os diques estreitos e irregulares de microgranito-aplito e as bandas félsicas nos enclaves granodioríticos (Figs. 6D e G).

Desta forma, o tipo, abundância e distribuição das feições de desequilíbrio sugerem que o MP marca a zona de recarga com magma máfico, aparentemente controlada pela Z. F. NW-SE que corta a porção central do CGSS (Fig. 4A). A distribuição do MH ao redor deste corrobora tal interpretação, sugerindo também que os episódios finais de interação teriam remobilizado, em intensidades variadas, as demais fácies já existentes (MS e SG). Isto pressupõe processo progressivo e cíclico, comum nos cenários de mistura de magmas (Bateman, 1995; Harper et al., 2004; du Bray et al., 2011; Miller et al., 2011), e bem evidenciado pela diversidade de feições texturais (Figs. 10D-F). Os enclaves microgranulares, embora pouco abundantes, revelam contrastes termais e composicionais distintos, registrados pelo aumento da granulação com a evolução na composição. A dispersão dos enclaves máficos indica que a viscosidade efetiva do granito hospedeiro ainda era baixa ( $<30 \%$ de cristais), permitindo processos hidrodinâmicos e pulverização de microenclaves (Fig. 6B). A homogeneização parcial enclave-granito em episódios mais tardios, resultante do menor contraste entre os polos da mistura, explica a relativa escassez de enclaves microgranulares e a heterogeneidade textural no MH (Figs. 6E-F). Neste caso, um dos polos equivaleria a magma previamente hibridizado, o que requer interação em profundidade onde o magma máfico seria mais abundante.

0 monzogranito seriado (MS) é também uma fácies híbrida, cujas feições são consistentes com um pulso precoce de magma sienogranítico remobilizado e hibridizado (texturas do plagioclásio e K-feldspato; Figs. 10B-C), quando os processos de interação foram favoráveis à redistribuição dos minerais. Isto justificaria o contato gradativo MS-MH/MP e a homogeneidade textural. A maior frequência de diques ou apófises de microgranitos e aplitos implica que o magma mais evoluído foi originado em profundidade, em câmara magmática ou fronts de solidificação sotopostos. A presença de schlieren de biotita ao redor destes diques (Figs. $6 \mathrm{H}-\mathrm{I})$, contudo, indica que o líquido magmático residual intrudiu o MS ainda parcialmente cristalino.

\section{Sienogranitos da borda - Fracionamento e acúmulo de voláteis}

0 fracionamento mineral extensivo nos sienogranitos é paralelo ao decréscimo abrupto da granulação no sentido centro-borda. Os registros de mistura de magmas no SG menos evoluído, embora escassos, corroboram a recarga máfica, cujo principal efeito parece ter sido o re-aquecimento do sistema, favorecendo à maturidade textural das porções previamente cristalizadas (textural aging; Horsman et al., 2010). Isto está registrado na granulação grossa ou muito grossa, história prolongada do plagioclásio rendilhado e abundância de oligoclásio reabsorvido pelo K-feldspato. Algumas evidências apontam para a geração de magmas sienograníticos em câmara subjacente, o que é referendado pela diversidade composicional das intrusões menores a leste-sudeste. Contudo, a expulsão de líquidos magmáticos residuais ricos em voláteis das zonas de interação teria contribuído para o extensivo fracionamento 
dos sienogranitos, e o acúmulo de voláteis nas porções apicais.

A textura miarolítica interconectada, nos bolsões félsicos (Figs. 7C-E), registra os paleocondutos da fase volátil magmática (FVM) em condições suprasolidus e, por consequência, anterior à diluição com fluidos externos (Candela \& Blevin, 1995; Candela, 1997). Segundo estes autores, a circulação da FVM ocorre in situ devido à conectividade dos poros na zona dinâmica de cristalização (= intervalo de cristalização) e/ou na forma de plumas ascendentes de líquidos magmáticos residuais ricos em voláteis. Isto explicaria contatos ora gradativos, ora bruscos dos bolsões miarolíticos com o sienogranito médio a fino (SMF). Tais feições implicam em magma com baixa cristalinidade, conteúdo elevado de voláteis $(\approx 1 / 3$ do volume do sistema) e pressões litostáticas inferiores a 200-300 MPa (Candela, 1997), ou 150-200 MPa (Thomas et al., 2009). Voláteis ricos em F são sugeridos pela presença crescente de fluorita, e aumento no conteúdo de elementos incompatíveis correlacionados ao F com a evolução dos sienogranitos (Y, Nb e ETR; Gastal, 1998). Os constituintes fundentes, como o F, têm efeitos significativos nos magmas uma vez que aumentam a difusividade química e a solubilidade da $\mathrm{H}_{2} \mathrm{O}$ e de elementos menos solúveis, e diminuem a viscosidade e as temperaturas solidus e liquidus (London \& Morgan, 2012). Portanto, os sienogranitos equivaleriam a magma fluido em que a saturação em voláteis foi sucessivamente postergada, favorecendo o extensivo fracionamento mineral, a circulação da FVM suprasolidus, formação da capa rica em voláteis, e a consequente expansão do sistema magmático. Tais feições justificam o distúrbio significativo do sistema isotópico $\mathrm{Rb}-\mathrm{Sr}$ nas fácies mais evoluídas (Vlach \& Cordani, 1986), e a remobilização tardi-magmática ou hidrotermal de zircões no SG (Gastal et al., 2010).

0 subsequente colapso do sistema com a exsolução dos voláteis, aliada à ruptura do teto segundo zonas de falhas, originou amplas margens resfriadas félsicas devido à abrupta desvolatilização (quenching), e a formação de brechas magmático-hidrotermais localizadas e similares àquelas vinculadas às cúpulas graníticas (Ross et al., 2002; Olivier et al., 2006). Fragmentos angulosos e escassa farinha de rocha, misturados à matriz juvenil nestas brechas (Figs. 7F-I e 11C-F), sugerem a maior importância do processo de fragmentação relativo ao de fluidização. Fluidização equivale ao processo mecânico que envolve o transporte de partículas sólidas por fluidos canalizados e pressurizados, o que produz a cominuição e o intenso arredondamento dos fragmentos devido ao choque entre eles e à interação fluido-clasto (McCallum, 1985; Olivier et al., 2006). Contudo, no CGSS, fluidização localizada é requerida para explicar a mistura de litoclastos diversos (Fig. 7F), as concentrações de grânulos de quartzo (Fig. 7G), e os clastos subarredondados na fração mal selecionada. Os fluidos liberados em condições subsolidus, misturados àqueles externos, teriam sido assim responsáveis pelo desenvolvimento do sistema hidrotermal que, ao remobilizar as encaixantes metavulcano-sedimentares, formou as ocorrências auríferas em greisens.

\subsection{Estruturas tectônicas regionais e o posicionamento do pluton}

0 alojamento da intrusão ocorreu na interseção de zonas de falhas pré-existentes, $\mathrm{N} 30-35^{\circ} \mathrm{E}$ e N55$-60^{\circ} \mathrm{W}$. Aquela NE-SW, situada a leste, representa estrutura profunda que poderia ter atuado como sistema de transferência de magma (mush columns; Marsh, 2000), sugerido no mapa magnético continuado para cima (Fig. 2B). Tais colunas representam os sistemas magmáticos ativos, consistindo em uma rede, verticalmente extensa, de pequenos reservatórios de magma conectados. Estas permanecem parcial ou totalmente cristalizadas por períodos prolongados, quando a frequência na atividade magmática é reduzida (1-5 m.a.), o que ocorre em ambiente com limitada geração de magma como o pós-colisional. Nos períodos de atividade, plutons em diferentes estágios de cristalização são remobilizados, resultando em processos e mecanismos de diferenciação magmática particular a cada um, e no maior efeito do fracionamento ao longo de toda a coluna.

O sistema de falhas NW-SE controla o contato sul do corpo intrusivo e o posicionamento do monzogranito porfirítico (MP; Figs. 4A e 8), que representa a região do reservatório em que ocorreram recargas sucessivas com magma mais máfico. Isto indica também o papel destas estruturas na localização dos reservatórios de magma sotopostos. Zonas de cataclase discretas nos granitos, nessa direção, sugerem que este sistema foi reativado no final da construção do pluton. Esta ideia é interessante, pois permite explicar a Z. F. Rio São Sepé (WNW-ESE a ENE-WSW) como fratura subsidiária de tensão (tipo T) do sistema transcorrente NW-SE esquerdo, que poderia ter evoluído e acomodado algum movimento. Desta forma, seria possível explicar zonas de cataclase discretas nos granitos, bem como a restrição de alinhamentos e sistema de fraturas de direção WNW-ESE nos arredores do CGSS (Fig. 8). O controle das direções N-S no contato do corpo de monzogranitos centrais parece estar refletindo descontinuidades litológico-estruturais das encaixantes, importantes na localização da intrusão precursora. Os mecanismos de crescimento e propagação do pluton são difíceis de visualizar, face ao desconhecimento de sua forma em profundidade. Todavia, é possível afirmar que as principais estruturas atuaram como zonas de fraqueza, por onde foram liberados os voláteis e líquidos residuais durante o colapso do sistema magmático. Deste modo, é possível inferir o papel, mesmo que reduzido, de mecanismos de soerguimento do teto durante a expansão do sistema magmático com o acúmulo de voláteis.

A similaridade no controle tectônico dos sistemas magmáticos alimentadores dos complexos graníticos 
São Sepé (CGSS) e Caçapava do Sul (CGCS) é fortemente sugerida, porém isto deve ser avaliado em estudos futuros que priorizem a análise geométrica e cinemática dos sistemas de falha. Os dois exibem idades similares (570-560 Ma), razões isotópicas do Pb-comum indicativas do envolvimento de crosta média e inferior (Gastal \& Lafon, 1998; Remus et al., 1999; 2000), e incluem granitos cálcio-alcalinos e ferrosos, embora a assinatura mais alcalina do CGSS seja indicada pelos elementos traço. A explicação mais provável para a natureza sintectônica do CGCS, consistente com o relaxamento tectônico comum aos ambientes pós-colisionais, seria sua proximidade à zona de cisalhamento frágil-dúctil estreita (NNE-SSW), posicionada a oeste (Bitencourt, 1983). Esta teria sido reativada em níveis crustais rasos com o desenvolvimento do sistema de falhas Santa Bárbara-Segredo (Fig. 1C), o qual junto com aquele N30-45ㄹ (Z. F. Cerro dos Cabritos) representam estruturas regionais importantes como revelado nos mapas magnéticos, mesmo sob a cobertura permiana a nordeste (Figs. 2-3).

As zonas de falha $\mathrm{N} 30-45^{\circ} \mathrm{E}$ (até $\mathrm{N} 25^{\circ} \mathrm{E}$ ) são subparalelas a zonas de cisalhamento dúctil, ativas durante a orogênese Dom Feliciano (640-620 Ma), no leste do escudo. Representam estruturas profundas, que condicionam corpo expressivo de serpentinitos e a movimentação tectônica das unidades neoproterozoicas da Bacia de Camaquã a leste do CGSS. O sistema de falhas N55-60 $\mathrm{W}$ desloca e interrompe o anterior, afetando também estas sequências neoproterozóicas ( $\mathrm{ca}$. 630-600 Ma), e condiciona o posicionamento do CGSS (570-560 Ma). Portanto, tais relações corroboram que os sistemas tectônicos $\mathrm{N} 30-45^{\circ} \mathrm{E}$ e N55- $60^{\circ} \mathrm{W}$ são mais antigos (Ribeiro, 1970), e vinculados ao final da orogênese Dom Feliciano. Por sua vez, tais sistemas são interrompidos pelas zonas de falha $\mathrm{N} 15-20^{\circ} \mathrm{E}$, restritas ao leste da região, e responsáveis pela formação do alto de Caçapava e sub-bacias cambro-ordovicianas da Bacia Camaquã. Isto referenda a proposta de Chemale Jr. (2000), de que representam um novo evento tectônico em regime transtensivo, cuja idade, balizada pelo CGCS, sugere que seja responsável pela retomada da atividade magmática, expressiva no final do Neoproterozóico. Durante este evento, aquelas falhas com orientação adequada $\left(\mathrm{N} 30-45^{\circ} \mathrm{E}\right)$ foram reativadas em maior intensidade, originando o sistema Santa Bárbara-Cerro dos Cabritos o qual, junto com o sistema AngélicaMato Grande (NNE-SSW), foi novamente reativado no Cambro-Ordoviciano. Este esboço tectônico preliminar reflete a necessidade de rever a interpretação do Siste-

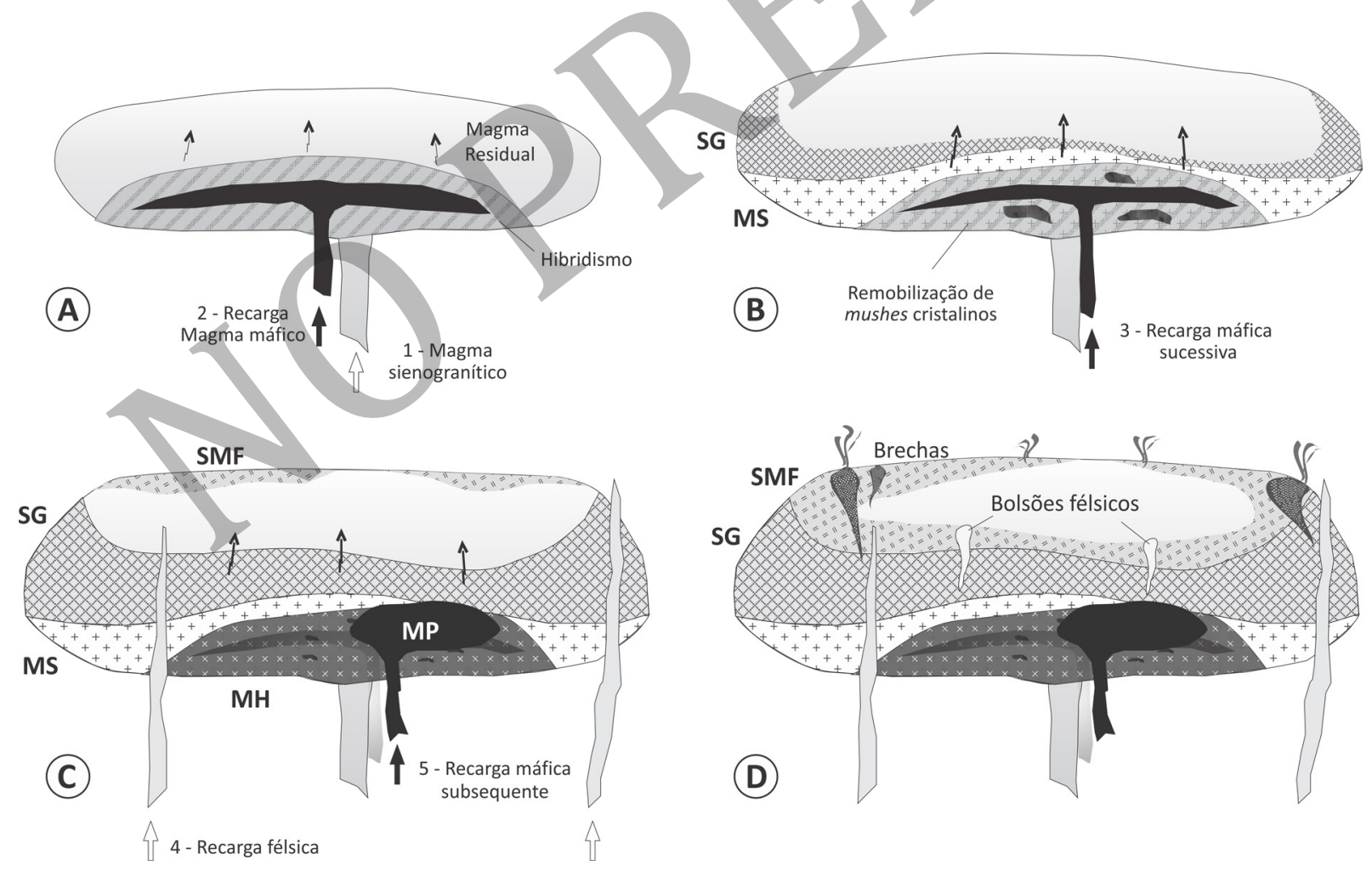

Figura 12. Modelo conceitual para construção do complexo granítico São Sepé: A - Formação da soleira de magma sienogranítico, em níveis crustais rasos, que se estratifica com recarga de magma máfico devido ao hibridismo na base e coleta de magmas residuais no topo; B - Episódios sucessivos de recarga máfica, nos períodos iniciais, favorecem a redistribuição de minerais e microenclaves máficos; com o declínio da atividade, as duas frações do magma residente começam a cristalizar (monzogranito seriado - MS e sienogranito grosso - SG), e são intrudidos por líquidos residuais originados dos mushes cristalinos nas zonas de interação (diques félsicos sinplutônicos); C - Recarga com magma félsico contribui para o crescimento da intrusão e evolução do líquido residual que inicia a cristalizar nas porções apicais (sienogranito médio a fino - SMF); episódios subsequentes de recarga máfica, em uma intrusão mais fria, promovem o aquecimento e maturidade textural das fácies cristalizadas, a remobilização de mushes cristalinos, a reintrusão de magmas hibridizados, e o maior subresfriamento termal e mixing parcial no polo máfico (monzogranitos porfirítico - MP e heterogranular - MH); e D - Processos finais envolvendo a migração de líquidos residuais ricos em voláteis, formação dos bolsões miarolíticos no topo e expansão do sistema magmático; na sequência, descompressão segundo zonas de falha e contatos originando as margens resfriadas félsicas (colapso-quenching) e brechas magmático-hidrotermais (canalização de líquidos e fluidos pressurizados); veja texto para os detalhes. 
ma de Falhas Irapuá, que segundo Ribeiro et al. (1966), reúne o conjunto de zonas de falhas NE-SW a NNE-SSW balizadas pela Z.F. Angélica a leste e Cerro dos Cabritos a oeste. As implicações são relevantes, uma vez que o mesmo coincide em parte com o limite entre domínios geotectônicos do escudo proposto por Fernandes et al. (1995).

\subsection{Modelo conceitual para construção do complexo gra- nítico}

A diversidade de texturas, ampla margem resfriada félsica, auréola de metamorfismo termal de baixo a médio grau, e os bolsões de cúpula granítica rica em voláteis, todos corroboram o posicionamento do CGSS em condições de epizona. Isto é consistente com pressões de 250-160 MPa, obtidas pelo geobarômetro do Al-anfibólio nos monzogranitos (formulação de Anderson \& Smith, 1995; Gastal, em preparação), cujos valores, contudo, são mais baixos que os estimados para a paragênese do metamorfismo termal (250-450 MPa; Matos et al., 2004).

As feições geológicas e petrográficas no CGSS oferecem farta documentação, aparentemente contraditória, que revela uma intrusão múltipla, construída por processos progressivos e cíclicos de recarga com magma máfico. Tal dinâmica de construção propiciou a coalescência de líquidos magmáticos residuais na porção superior. Exemplos similares incluem plutons múltiplos, com exposições excelentes e contrastes composicionais extremos (gabro-granito), muitos dos quais associados às capas félsicas (Harper et al., 2004; Haapala \& Lukkari, 2005; Lux et al., 2007; Horsman et al., 2010; du Bray et al., 2011). Um dos pré-requisitos de qualquer modelo para a construção de um pluton múltiplo, como o CGSS, é sua localização na porção epizonal de uma coluna vertical de magma, a qual teria sido controlada pelas estruturas pré-existentes $\mathrm{N} 30-45^{\circ} \mathrm{E}$ e $\mathrm{N} 55-60^{\circ} \mathrm{W}$.

Os estágios idealizados na construção do CGSS, sintetizados na figura 12, seguem o modelo proposto por Harper et al. (2004), com algumas adaptações (Bateman, 1995; Miller et al., 2011). A soleira precursora de magma sienogranítico, posicionada nos níveis rasos da coluna vertical de magma-mush, foi remobilizada na base com magma máfico (Fig. 12A). Os processos de interação favoreceram o hibridismo e liberação de líquidos magmáticos residuais coletados no topo, resultando na estratificação do magma residente. Episódios frequentes de recarga máfica nos períodos iniciais teriam favorecido os processos hidrodinâmicos e, com isto, a redistribuição de minerais e pulverização de microenclaves. Com o declínio desta atividade, parcelas significativas do magma residente hibridizado solidificaram lentamente, resultando na formação do monzogranito seriado que é texturalmente homogêneo (MS; Fig. 12B).

Os mushes cristalinos, na zona de interação, foram sucessivamente remobilizados, de modo que concentram enclaves microgranulares e feições diversificadas de desequilíbrio. Os líquidos residuais liberados destes fronts originaram diques félsicos e estreitos, sinplutônicos. Ao mesmo tempo, a lenta cristalização dos sienogranitos (SG) inicia a partir do magma coletado acima. Neste caso, a granulação decresce abruptamente do centro para a borda da intrusão, em face do crescente gradiente termal nesse sentido. A intrusão de magmas félsicos, originados em câmaras sotopostas, teria contribuído para o crescimento e expansão da intrusão e a evolução do magma residual que começa a cristalizar nas porções apicais, formando o sienogranito médio a fino (SMF; Fig. 12C). Eventos subsequentes de recarga máfica na base, em uma intrusão parcialmente solidificada e mais fria, acarretaram: (a) o reaquecimento, e a consequente maturidade textural e eventual erosão termal das fácies cristalizadas (MS e SG); (b) a remobilização dos mushes cristalinos e geração de instabilidades que propiciaram a reintrusão e co-mingling de líquidos hibridizados; e (c) o maior subresfriamento termal e mixing parcial no polo máfico. Disto resultou a formação do monzogranito porfirítico (MP) circundado pelo tipo heterogranular (MH), que equivale aos mushes remobilizados. Os processos finais envolveram a concentração de líquidos residuais ricos em voláteis $\left(\mathrm{H}_{2} \mathrm{O}\right.$ e F $)$ nas porções apicais, com a formação de bolsões félsicos miarolíticos e expansão do sistema magmátíco. Na sequência, teria ocorrido o colapso do sistema com a descompressão e a formação das margens resfriadas félsicas e brechas magmático-hidrotermais (Fig. 12D).

\section{Conclusões}

O modelo conceitual proposto para o complexo granítico São Sepé assume a construção de um pluton composto, via ciclos intrusivos envolvendo magmas que evoluíram de forma independente ao longo da coluna vertical de magma. Os detalhes, com certeza, deverão ser, no futuro, alterados e adequados à forma em profundidade do pluton. Todavia, este modelo é capaz de explicar relações de intrusão ambíguas, não resolvidas ao assumir duas intrusões distintas, como é o caso da manutenção da granulação grossa a muito grossa nos sienogranitos ao longo do contato com o corpo de monzogranitos centrais (Fig. 7A). Estes monzogranitos, por sua vez, exibem tipos cuja textura porfirítica grossa e fina seria um indicativo de que são intrusivos nos sienogranitos (Fig. 6A), supostamente mais jovens.

0 conjunto de feições revela que os sienogranitos representam magmas altamente móveis e potencialmente eruptivos, formados pela coalescência de pequenos pulsos. Durante o colapso do sistema magmático com a descompressão, houve a mobilização de grande volume de líquidos residuais, corroborando que o CGSS representa uma das câmaras magmáticas epizonais, alimentadoras do vulcanismo da Formação Acampa- 
mento Velho.

Deste modo, o presente trabalho exemplifica a relevância das texturas e estruturas, que são registros dos processos magmáticos preservados em diferentes níveis e intensidades durante a construção de um pluton, e cuja investigação detalhada deve preceder aos modelamentos geoquímicos e isotópicos. Por fim, a avaliação mesmo que preliminar de estruturas frágeis, nos desafia a olhá-las em maior detalhe ao discutir a evolução de corpos intrusivos epizonais, visando estabelecer os padrões de sua propagação e crescimento.

Agradecimentos- Somos gratos a Sílvio Vlach e revisor anônimo, pela proveitosa contribuição que engrandeceu em muito as ideias aqui expostas, e aos editores da revista Pesquisas em Geociências que possibilitaram sua veiculação. Agradecemos à CPRM - Serviço Geológico do Brasil, que cedeu os dados aerogeofísicos, e a todos os bolsistas de IC que participaram em diferentes momentos deste trabalho. 0 desenvolvimento do mesmo foi possível graças aos recursos provenientes dos auxílios CNPq no 475388/2008-9, e PRONEX-FAPERGS nำ 10/0045-6.

\section{Referências}

Aboarrage, A.M. \& Lopes, R. da C. 1986. Projeto A Borda leste da Bacia do Paraná: integração geológica e avaliação econômica. Folha 1 : 100000, São Sepé. Departamento Nacional da Produção Mineral, Companhia de Pesquisas Recursos Minerais, Porto Alegre.

Anderson, J.L. \& Smith, D.R. 1995. The effects of temperature and $\mathrm{fO}_{2}$ on the Al-in-hornblende barometer. American Mineralogist, 80(5/6): 549-559.

Annen, C. 2009. From plutons to magma chambers: Thermal constraints on the accumulation of eruptible silicic magma in the upper crust. Earth and Planetary Science Letters, 284: 409-416.

Bateman, R. 1995. The interplay between crystallization, replenishment and hybridization in large felsic magma chambers. Earth Science Reviews, 39: 91-106.

Bartley, J.M., Coleman, D.S. \& Glazner, A.F. 2008. Incremental pluton emplacement by magmatic crack-seal. Transactions of the Royal Society of Edinburgh: Earth Science, 97: 383-396.

Bitencourt, M.F. 1983. Geologia, petrologia e estrutura dos metamorfitos da região de Caçapava do Sul, RS. Porto Alegre, 161p. Dissertação de Mestrado, Curso de Pós-graduação em Geociências, Instituto de Geociências, Universidade Federal do Rio Grande do Sul.

Borba, A.W., Mizusaki, A.M.P., Santos, J.O.S., McNaughton, N.J., Onoe, A. T. \& Hartmann, L.A. 2008. U-Pb zircon and ${ }^{40} \mathrm{Ar}-$ ${ }^{39} \mathrm{Ar} \mathrm{K}$-feldspar dating of syn-sedimentary volcanism of the Neoproterozoic Maricá Formation: constraining the age of foreland basin inception and inversion in the Camaquã Basin of southern Brazil. Basin Research, 20: 359375

Briggs, I.C. 1974. Machine contouring using minimum curvature. Geophysics, 39: 39-48.

Buddington, A.F. 1959. Granite emplacement with special reference to North America. Geological Society of America Bulletin, 70: 671-748.

Candela, P.A. 1997. A review of shallow, ore-related granites:
Textures, volatiles, and ore metals. Journal of Petrology, 38: 1619-1633.

Candela, P.A. \& Blevin, P.L. 1995. Do some miarolitic granites preserve evidence of magmatic volatile phase permeability? Economic Geology, 90: 2310-2316.

Campos Neto, M.C. \& Figueiredo, M.C.H. 1995. The Rio Doce Orogeny, south-eastern Brazil. Journal of South America Earth Science, 8: 143-162.

Chemale Jr., F. 2000. Evolução geológica do Escudo Sul-riograndense. In: M. Holz \& L.F. De Ros (eds.) Geologia do Rio Grande do Sul. Porto Alegre, CIGO-UFRGS, p. 13-52.

Coleman, D.S., Gray, W. \& Glazner, A.F. 2004. Rethinking the emplacement and evolution of zoned plutons: Geochronologic evidence for incremental assembly of the Tuolumne Intrusive Suite, California. Geology, 32: 433-436.

Cordell, L. \& Grauch, V.J.S. 1985. Mapping basement magnetization zones from aeromagnetic data in the San Juan Basin, New Mexico. In: Hinze, W. J. (ed.). The utility of regional gravity and magnetic anomalies maps. Society of Exploration Geophysicists, cap. 16: 181-197.

Costa, A.F.U., Fernandes, L.A.D., Shukowsky, W., Nardi, L.V.S. \& Bitencourt, M.F. 1995. Teste dos modelos tectônicos e de posicionamento do complexo granítico Caçapava do Sul através de estudos de modelagem gravimétrica 3D. Revista Brasileira de Geofísica, 13(2): 91-101.

Corti, G., Moratti, G. \& Sani, F. 2005. Relations between surface faulting and granite intrusions in analogue models of strike-slip deformation. Journal of Structural Geology, 27: 1547-1562.

CPRM. Companhia de Pesquisas e Recursos Minerais. 2007. Mapa Geológico do Estado do Rio Grande do Sul. Porto Alegre. Projeto Geologia do Brasil ao Milionésimo - Programa Geologia do Brasil, CPRM - Serviço Geológico do Brasil, escala 1: 750.000 .

Crawford, B.L., Betts, P.G. \& Aillères, L. 2010. An aeromagnetic approach to revealing buried basement structures and their role in the Proterozoic evolution of the Wernecke Inlier, Yukon Territory, Canada. Tectonophysics, 490: 2846.

Cruden, A.R. 1998. On the emplacement of tabular granites. Journal of the Geological Society, 155: 853-862.

Cruden, A.R. \& McCaffrey, K.J.W. 2001. Growth of plutons by floor subsidence: Implications for rates of emplacement, intrusion spacing and melt-extraction mechanisms. Physics and Chemistry of the Earth, Part A, 26: 303-315.

de Saint-Blanquat, M., Horsman, E., Habert, G., Morgan, S., Vandeshaeghe, O., Law, R. \& Tikoff, B. 2011. Multiscale magmatic cyclicity, duration of pluton construction, and the paradoxical relationship between tectonism and plutonism in continental arcs. Tectonophysics, 500: 20-33.

du Bray, E.A., Bacon, C.R., John, D.A., Wooden, J.L. \& Mazdab, F.K. 2011. Episodic intrusion, internal differentiation, and hydrothermal alteration of the Miocene Tatoosh intrusive suite south of Mount Rainier, Washington. Geological Society of America Bulletin, 123: 534-561.

Fernandes, L.A.D., Menegat, R., Costa, A.F.U., Koester, E., Porcher, C.C., Tommasi, A., Kraemer, G., Ramgrab, G.E. \& Camozzato, E. 1995. Evolução tectônica do Cinturão Dom Feliciano no Escudo Sul-rio-grandense: parte II - Uma contribuição a partir das assinaturas geofísicas. Revista Brasileira de Geociências, 25(4): 375-384.

Fernandez, A.N. \& Barbarin, B. 1991. Relative rheology of coeval mafic and felsic magmas: Nature of resulting interaction processes. Shape and mineral fabrics of mafic 
microgranular enclaves. In: J. Didier \& B. Barbarin (eds.) Enclaves and Granite Petrology. Developments in Petrology 13, Elsevier Sci. Publishers, p. 253-262.

Gastal, M.C.P. 1998. Suite Intrusiva Saibro, RS: Avaliação de um Modelo Petrológico. Porto Alegre, 365 p. Tese de Doutorado, Programa de Pós-graduação em Geociências, Instituto de Geociências, Universidade Federal do Rio Grande do Sul.

Gastal, M.C.P. \& Lafon, J.M., 1998. Gênese e evolução dos granitóides metaluminosos de afinidade alcalina da porção oeste do Escudo Sul-rio-grandense: geoquímica e isótopos de $\mathrm{Rb}-\mathrm{Sr}$ e $\mathrm{Pb}-\mathrm{Pb}$. Revista Brasileira de Geociências, 28(1): 11-28.

Gastal, M.C.P., Lafon, J.M. \& Chemale Jr., F. 2010. U-Pb and $\mathrm{Pb}-\mathrm{Pb}$ zircon ages of Neoproterozoic-Eopaleozoic granites from the western portion of the southern Brazilian Shield. In: SOUTHERN AMERICA SYMPOSIUM ON ISOTOPE GEOLOGY, 7, 2010. Brasilia. Extended Abstracts, 4 p.

Grocott, J., Arévalo, C., Welkner, D. \& Cruden, A. 2009. Fault-assisted vertical pluton growth: Coastal Cordillera, north Chilean Andes. Journal of the Geological Society, 166: 295-301.

Gudmundsson, A. 2011. Deflection of dykes into sills at discontinuities and magma-chamber formation. Tectonophysics, 500: 50-64.

Haapala, I. \& Lukkari, S. 2005. Petrological and geochemical evolution of the Kymi stock, a topaz granite cupola within the Wiborg rapakivi batholiths, Finland. Lithos, 80: 347 362 .

Harper, B.E., Miller, C.F., Koteas, C., Gates, N.L., Wiebe, R.A., Lazzareschi, D.S. \& Cribb, J.W. 2004. Granites, dynamic magma chamber processes and pluton construction: the Aztec Wash pluton, Eldorado Mountains, Nevada, USA. Transactions of the Royal Society of Edinburgh: Earth Science, 95: 277-295.

Hibbard, M.J. 1995. Petrography and Petrogenesis. N. Jersey, Prentice Hall, 587 p.

Hiller, J.K. \& Smith, M. 2008. Residual relief separation: digital elevation model enhancement for geomorphological mapping. Earth Surface Processes and Landforms, 33: 2266-2276

Hogan, J.P., Price, J.D. \& Gilbert, M.C. 1998. Magma traps and driving pressure: consequences for pluton shape and emplacement in an extensional regime. Journal of Structural Geology, 20: 1155-1168.

Horsman, E., Morgan, S., de Saint-Blanquat, M., Habert, G., Nugent, A., Hunter, R.A. \& Tikoff, B. 2010. Emplacement and assembly of shallow intrusions from multiple magma pulses, Henry Mountains, Utah. Earth and Environmental science Transactions of the Royal Society of Edinburgh, 100: 117-132.

Jackson, V.N., Ramos, V.A, Terry, S.A \& Zuzek, A.B. 1973. Projeto Aerogeofísico Camaquã, Estado do Rio Grande do Sul. Porto Alegre, Texas Instruments, DNPM/CPRM/CENEN, 208 p. (inédito).

Kazmierczak, T. de S. 2006. Mapeamento da Bacia de Camaquã com a utilização de dados geofísicos, geologia e sensoriamento remoto. Porto Alegre, 103 p. Dissertação de mestrado, Programa de Pós-graduação em Geociências, Instituto de Geociências, Universidade Federal do Rio Grande do Sul.

Kirkland, C.L., Alsop, G.I. \& Prave, A.R. 2008. The brittle evolution of a major strike-slip fault associated with granite emplacement: a case study of the Leannan Fault, NW Ire- land. Journal of the Geological Society, 165: 341-352.

Kokkalas, S. \& Aydin, A. 2013. Is there a link between faulting and magmatism in the south-central Aegean Sea? Geological Magazine, 150(2): 193-224.

Le Maitre, R.W. (Ed.). 2002. A Classification of Igneous rocks and Glossary of terms: recommendations of the International Union of Geological Sciences Subcommission on the Systematics of Igneous Rocks. Oxford, Blackwell Scientific Publications, 193p.

Li, X. 2006. Understanding 3D analytic signal amplitude. Geophysics, 71(2): L13-L16.

London, D. \& Morgan, G.B. 2012. The pegmatite puzzle. Elements, 8: 263-268.

Lux, D.R., Hooks, B., Gibson, J.P. \& Hogan, J.P. 2007. Magma interactions in the Deer Isle granite complex, Maine: field and textural evidence. The Canadian Mineralogist, 45: 131-146.

Marsh, B. D. 2000. Magma chambers. In: Sigurdsson, H. (Ed.). Encyclopedia of Volcanoes, Academic Press, p. 191-206.

Matos, I.C., Philipp, R.P., Mexias, A.S. \& Gomes, M.E.B. 2004. Metamorfismo de contato no complexo Bossoroca, porção SW do complexo granítico São Sepé, RS. Revista Brasileira de Geociências, 34: 1-10.

Matzel, J.E.P., Bowring, S.A. \& Miller, R.B. 2006. Time scales of pluton construction at differing crustal levels: examples from the Mount Stuart and Tenpeak intrusions, North Cascades, Washington. Geological Society of America Bulletin, 118: 1412-1430.

McCallum, M.E. 1985. Experimental evidence for fluidization processes in breccias pipe formation. Economic Geology, 80: 1523-1543.

Menand, T. 2011. Physical controls and depth of emplacement of igneous bodies; A review. Tectonophysics, 500:11-19.

Michaut, C. \& Jaupart, C. 2011. Two models for the formation of magma reservoirs by small increments. Tectonophysics, 500: 34-49.

Miller, C.F., Furbish, D.J., Walker, B.A., Claiborne, L.L., Koteas, G.C., Bleik, H.A. \& Miller, J.S. 2011. Growth of plutons by incremental emplacement of sheets in crystal-rich host: Evidence from Miocene intrusions of the Colorado River region, Nevada, USA. Tectonophysics, 500: 65-77.

Minty, B.S.R. 1991. Simple micro-levelling for aeromagnetic data. Exploration Geophysics, 22: 591-592.

Nabighian, M.N. 1972. The analytic signal of two-dimensional magnetic bodies with poligonal cross-section: its properties and use for automated anomaly interpretation. Geophysics, 37: 507-517.

Nabighian, M.N. 1974. Additional comments on the analytic signal of two-dimensional magnetic bodies with polygonal cross-section. Geophysics, 39: 85-92.

Olivier, N.H.S., Rubenach, B. Fu, Baker, T., Blenkinsop, T.G., Cleverley, J.S., Marshall. L.J. \& Ridd, P.J. 2006. Granite-related overpressure and volatile release in the mid crust: fluidized breccias from the Cloncurry District, Australia. Geofluids, 6: 346-358.

Passchier, C.W. \& Trouw, R.A. 2005. Microtectonics. 2a Ed., Heidelberg, Springer-Verlag, 366 p.

Petford, N., Cruden, A.R., McCaffrey, K.J.W., Vigneresse, J.-L. 2000. Granite magma formation, transport and emplacement in the Earth's crust. Nature, 408: 669-673.

Pitcher, W.S. 1978. The anatomy of a batholith. Journal of the Geological Society, 135: 157-182.

Pitcher, W.S. 1997. The nature and origin of granite. Chapman and Hall, 2 ${ }^{\mathrm{a}}$ ed., London, 377 p. 
Porcher, C.A. \& Lopes, R.C. 2000. Programa Levantamentos Geológicos Básicos do Brasil - Cachoeira do Sul (folha SH.22-Y-A), Porto Alegre, CPRM - Serviço Geológico do Brasil. 1 CD-Room.

Porcher, C.A., Leites, S.R., Ramgrab, G. \& Camozzato, E. 1995. Programa levantamentos geológicos básicos do $B \quad r$ a sil: Passo do Salsinho, Folha SH-22-Y-AI-4, estado do Rio Grande do Sul. Porto Alegre, CPRM - Serviço Geológico do Brasil, $356 \mathrm{p}$.

Remus, M.V.D., McNaughton, N.J., Hartmann, L.A., Koppe, J.C., Fletcher, I.R., Groves, D.I., Pinto, V.M. 1999. Gold in the Neoproterozoic juvenile Bossoroca Volcanic Arc of southernmost Brazil: isotopic constraints on timing and sources. Journal of South America Earth Sciences, 12: 349-366.

Remus, M.V.D., Hartmann, L.A., McNaughton, N.J., Groves, D.I. \& Fletcher, I.R 2000. The link between hydrothermal epigenetic copper mineralization and the Caçapava granite of the Brasiliano Cycle in southern Brazil. Journal of South American Earth Science, 13: 191-216.

Ribeiro, M.J. 1978. Mapa previsional do cobre no Escudo Sul-Riograndense. Nota Explicativa. Departamento da Produção Mineral, Brasília. Série Geologia, 3: 104 p.

Ribeiro, M. 1970. Geologia da Folha Bom Jardim, RGS. Boletim do Departamento Nacional da Produção Mineral, Divisão de Geologia e Mineralogia, 247, 141 p.

Ribeiro, M., Bocchi, P.R., Figueiredo Filho, P.M. \& Tessari, R.I. 1966. Geologia da quadrícula de Caçapava do Sul, RS. Boletim do Departamento Nacional da Produção Mineral, Divisão de Geologia e Mineralogia, 127, 232 p.

Roest, W.R., Verhoef J. \& Pilkington, M. 1992. Magnetic interpretation using the 3-D analytic signal. Geophysics, 57 (1): 116-125.

Ross, P.S., Jébrak, M. \& Walker, B.M. 2002. Discharge of hydrothermal fluids from a magma chamber and concomitant formation of a stratified breccia zone at the Questa porphyry molybdenum deposit, New Mexico. Economic Geology, 97: 1679-1689.

Saalmann, K., Gerdes, A., Lahaye, Y., Hartmann, L.A., Remus, M.V.D. \& Läufer, A. 2011. Multiple accretion at the eastern margin of the Rio de la Plata craton: the prolonged Brasiliano orogeny in southernmost Brazil. International Journal of Earth Science (Geol. Rundsch), 100: 355-378.

Sartori, P.L.P. 1978. Petrologia do complexo Granítico de São Sepé, R.S. São Paulo, 195p. Tese de Doutorado, Instituto de Geociências, Universidade de São Paulo.

Sillitoe, R.H. 1985. Ore-related breccias in volcanoplutonic arcs. Economic Geology, 80: 1467-1514.

Soliani Jr., E. 1986. Os dados Geocronológicos do Escudo Sul-rio-grandense e suas Implicações de Ordem Geotectônica. São Paulo, 340 p. Tese de Doutorado, Instituto de Geociências, Universidade de São Paulo.

Sommer, C.A., de Lima, E.F., Nardi, L.V.S., Figueiredo, A.M.G. \&
Pierosan, R. 2005. Potassic and low- and high-Ti mildly alkaline volcanism in the Neoproterozoic Ramada Plateau, southernmost Brazil. Journal of South American Earth Sciences, 18: 237-254.

Thomas, R., Davidson, P., Rhede, D. \& Leh, M. 2009. The miarolitic pegmatites from the Königshain: contribution to understanding the genesis of pegmatites. Contribution to Mineralogy and Petrology, 157: 505-523.

UFRGS. Universidade Federal do Rio Grande do Sul. 1997. Mapeamento geológico 1: 25 000. Projeto Vila Nova. Porto Alegre. Trabalho de Conclusão, Curso de Geologia, Instituto de Geociências, Universidade Federal do Rio Grande do Sul.

UFRGS. Universidade Federal do Rio Grande do Sul. 2002. Mapeamento geológico 1:25000 de parte das folhas São Sepé (MI2982/2) e Passo do Salsinho (MI2982/4): Projeto São Sepé. Porto Alegre. Trabalho de Conclusão, Curso de Geologia, Instituto de Geociências, Universidade Federal do Rio Grande do Sul.

Veneziani, P. \& Anjos, C.E. 1982. Metodologia de interpretação de dados de sensoriamento remoto e aplicações em geologia. São Paulo, Publicação n-INPE-2227-MD/014, 61 p.

Vernon, R.H. 2004. A practical guide to Rock Microstructure. Cambridge, Cambridge Univ. Press, 594 p.

Vigneresse, J.-L., Tikoff, B. \& Améglio, L. 1999. Modification of the regional stress field by magma intrusion and formation of tabular granitic plutons. Tectonophysics, 302: 203-224.

Viola, G., Kounov, A., Andreoli, M.A.G. \& Mattila, J. 2012. Brittle tectonic evolution along the western margin of South Africa: More than 500 Myr of continued reactivation. Tectonophysics, 514-517: 93-114.

Vlach, S.R.F. \& Cordani, U.G. 1986. A sistemática Rb/Sr em rochas granitóides: considerações interpretativas, limitações e exemplos brasileiros. Revista Brasileira de Geociências, 16(1): 38-53.

Walker Jr., B.A., Miller, C.F., Claiborne, L.L., Wooden, J.L. \& Miller, J.S. 2007. Geology and geochronology of the Spirit Mountain batholiths, southern Nevada: Implications for timescales and physical processes of batholiths construction. Journal of Volcanology and Geothermal Research, 167: 239-262.

Wark, D.A. \& Stimac, J.A. 1992. Origin of mantle (rapakivi) feldspars: experimental evidence of a dissolution and diffusion-controlled mechanism. Contribution to Mineralogy and Petrology, 3: 345-361.

Williams, H.A. \& Betts, P.G. 2007. Imaging links between lithospheric architecture and surface geology in the Proterozoic Curnamona Province, Australia. Journal of Geophysical Research, 112: B07411 (doi: 10.1029/2007JB004966), $18 \mathrm{p}$. 


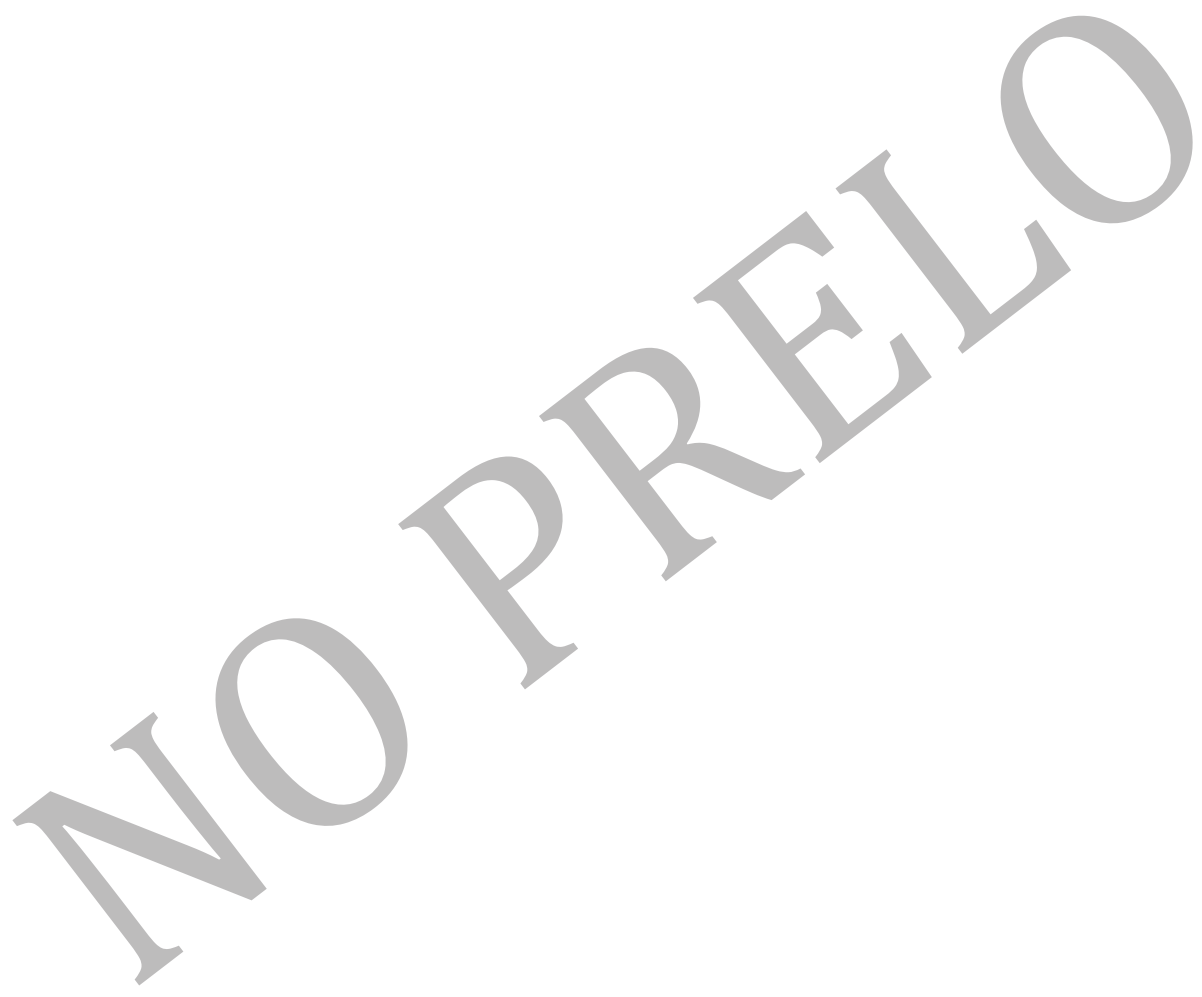

